Article

\title{
Exploring Ethical Business in Central Europe: Leaders' Values and Perspectives on Good Practices
}

\author{
Áron Perényi ${ }^{1, *} \mathbb{0}$, Christopher Selvarajah ${ }^{1} \mathbb{D}$, Janusz Tanas ${ }^{2}$, Zuzana Tučková ${ }^{3}$, \\ Anna Odrowaz-Coates ${ }^{4}$, Brigitta Tóth-Bozó ${ }^{5}$ and Martina Minarova ${ }^{6}$ \\ 1 Swinburne Business School, Swinburne University of Technology, Melbourne VIC 3122, Australia; \\ cselvarajah@swin.edu.au \\ 2 Peter Faber Business School, Australian Catholic University, East Melbourne VIC 3002, Australia; \\ Janusz.Tanas@acu.edu.au \\ 3 Faculty of Logistics and Crisis Management, Tomas Bata University in Zlín, Studentské nám., \\ 1532 Uherské Hradiště, Czech Republic; tuckova@utb.cz \\ 4 Social Pedagogy Department, Maria Grzegorzewska University in Warsaw, 02-353 Warsaw, Poland; \\ acoates@aps.edu.pl \\ 5 Department of Economics, Budapest University of Technology and Economics, Magyar tudósok körútja 2., \\ 1111 Budapest, Hungary; brigitta.bozo88@gmail.com \\ 6 Faculty of Economics, Matej Bel University, 97401 Banská Bystrica, Slovakia; martina.minarova@umb.sk \\ * Correspondence: aperenyi@swin.edu.au; Tel.: +61-3-9214-8078
}

Received: 31 October 2019; Accepted: 14 January 2020; Published: 16 January 2020

check for updates

\begin{abstract}
Weaknesses in the institutional environment of Central Europe challenge the sustainability of economic development. Institutional theory stipulates that institutions drive economic development, and institutions are configured by individual values and practices. The World Governance Indicators, the Corruption Perception Index, and the Doing Business Indicators indicate weaknesses in the institutional environments of the Visegrád countries. This paper explores the micro level perspective of institutions, focusing on values and practices, in terms of leadership and ethics. A survey of 868 private and public sector managers from Czech Republic, Hungary, Poland, and Slovakia provides evidence that leadership practices and ethical values are congruent, suggesting a positive influence on the institutional environment. The results also provide evidence for the presence of the gap, spanning between the micro and the macro level factors affecting sustainable economic development. These results imply that a bottom-up view of sustainable economic development is more suitable to the Central European context, and promotion of sustainable economic development needs to focus on the micro level factors.
\end{abstract}

Keywords: sustainable economic development; institutions; leadership; ethics; Central Europe

\section{Introduction}

This article builds on the fundamental view that institutions are essential for economic development [1]. Acemoglu and Robinson [2] argue that differences between economic development across nations can be explained by the differences in their relevant institutions. North's definition of institutions is "rules of the game in a society or, more formally ... the humanly devised constraints that shape human interaction" ([3] p. 3). Hodgson [4] builds on this definition and argues that institutions are systems of established social rules, structuring social interactions. Institutions are made up of rules and practices, which are relatively enduring [5].

Since institutions are viewed as essential causes of economic development [6], institutions also exercise substantial effect on economic sustainability. Sustainability consists of economic, social, and environmental dimensions [7]. Although institutional theory also captures the political [5] and 
environmental [8] dimensions of sustainability, economic development theorists focus on economic sustainability [9].

In this article, we focus on the micro level manifestation of practices and values defining the way things are done [3]. We investigate the relationship between the leadership practices and ethical values of managers in Central Europe. Vaduva et al. [10] examine the phenomena of leadership and ethics in Eastern Europe, highlighting a range of gaps in the body of context specific knowledge in the area, warranting further, comparative research in the field.

While scholars argue that the concept of ethical leadership is hard to capture [11], due to the normative aspect of ethics, and that descriptive approaches to ethical leadership are unlikely to deliver further insights [12], there is a call for further research on testing the positive outcomes of ethical leadership, and the influence of culture on the relationship between leadership and ethics [13].

There is evidence to demonstrate that business performance and other organizational outcomes are driven by ethical leadership [14], although support for this assertion is not unanimous amongst scholars [15]. Business level leadership ethics in turn influences macro level societal outcomes [16], and in particular asserts global, systemic effects on the economic environment [17]. The relationship between leadership and ethics influences how companies impact this global environment and through that, effect public interest [18]. De Jong and van Ees [19] emphasize the importance of looking at ethical issues at multiple levels, with the purpose of 'opening black boxes' of explanations.

But what is the relationship between leadership and ethics? Ciulla [20] points out that this connection is strong but sometimes controversial. Levine and Boaks [21] direct scholarly attention to the necessity of testing this relationship, while Hornett and Fredricks [22] call for fundamentally re-addressing leadership theories from an ethical perspective. There is reasonable consensus among scholars, that ethics in leadership follows a pattern, in which ethical behaviors in organizations are driven by the ethical values of their members [23]. Within organizations, ethical values of leaders positively impact the ethical conduct of staff [24], although under performance pressure, ethical leadership can also inspire unethical staff behavior [25] and in certain cases, subordinates' ethical values correspond more strongly to organizational norms than individual supervisor attributes [26].

The relationship between leadership and ethics has been investigated in different contexts in multiple countries; private and public sectors; and across varying management levels [15,27-29]. From a cross-cultural perspective, the GLOBE (Global Leadership and Organizational Behavior Effectiveness Research) project provided substantial insight into ethical components of leadership from a Western theoretical perspective [30]. However, researchers have been arguing for a more balanced view of leadership ethics across cultural contexts, integrating an Eastern view of leadership [31].

A multi-level view of ethics in leadership has been commonly adopted by researchers. Mozumder [24] for instance highlights the importance of incorporating perspectives of multiple organizational levels of analysis. It is essential to identify and capture the views of key informants from different levels of organizations to allow for generating a balanced view of the interaction between leadership and ethics. The concept of ethics in leadership is highly relevant for leaders facing complex and multifaceted challenges [32]. Pucic [33] argues that managers' opinions on ethical leadership are good reflections of the actual situation. This research joins the series of leadership research, to evaluate the relationship between leadership practices and ethical values [34].

Based on this current understanding of the role of leadership and ethics in driving institutions, this study aims to contribute to body of knowledge by:

1. Testing the relationship between leadership practices and ethical values in organizations;

2. Contextualizing the study in the business and cultural environment of four Central European nations (Czech Republic, Hungary, Poland, and Slovakia).

The paper continues with the review of relevant literature and an introduction of the conceptual framework, followed by the explanation of the measures and data collection procedures used. The data analysis section provides the description of exploratory factor analysis to validate the scales used, 
and an evaluation of the relationships between the emerging dimensions of leadership practices and ethical values by means of correlation analysis. The discussion of the results focuses on one hand on the explanation of the emergent dimensions of leadership and ethics, on the other hand the relationships between these dimensions identified. The discussion contrasts the findings of the individual level analysis to the attributes of the context in which the data was collected. The paper is concluded by a summary of limitations, theoretical and practical implications, and recommendations for further research.

\section{Theoretical Framework}

The theoretical framework of this paper rests on two pillars: the relationship leadership and ethics and the quality of the institutional environment for doing business (institutional economics). The first section of the review of literature discusses the connection between leadership and ethics, which is followed by the introduction into context specific leadership theories. The key characteristics of the institutional environment for doing business in the four Central European nations are described, followed by the definition of the research model and propositions.

\subsection{Leadership and Ethics}

Leadership research has developed through four generations of theoretical approaches, examining: (1) leader traits, (2) leader actions, (3) the context in which leadership takes place, and (4) leader values [35]. Traditionally, behavioral leadership research has focused on identifying and categorizing behaviors used by leaders [34], while follower-centric theories attribute good leadership outcomes to follower actions [36]. Sometimes also referred to as a style or a skill, leadership behavioral and follower-centric studies examined what leaders and followers do and how they act $[37,38]$.

Ethical leadership research—as a fourth-generation leadership theoretical approach-has focused on how ethical leadership affects organizational outcomes [14]. However, according previous empirical results, evidence is presented that leader traits, leader actions, and the context of leadership all have positive relationships to organizational outcomes [35]. Therefore, in order to explore the right level at which leadership and ethics connect, we need to identify and assess leadership traits, actions, context, and values, and how these relate to organizational ethical values and outcomes. An ethical issue is present, when "a person's actions, if performed freely, may harm or benefit others" ([39] p. 367). Nguyen and Biderman [28] emphasize that ethical issues lead to ethical awareness, judgement, intent, and behavior. Ethical values can be grouped in three major areas: corruption [40]; governance [41]; and transparency [30,42]. Although this grouping is commonly employed, studies often find that these dimensions overlap in the views of respondents [30].

Brown and Trevino [18] identify the link between ethics and leadership by introducing ethical/moral leadership theories. Leaders inspiring good (and bad) conduct are captured in the authentic leadership theory [43], but authentic leadership theory does not encompass the totality of the ethical leadership concept [36]. In fact, both authentic and ethical leadership theories-along with spiritual and servant leadership theory-are captured within the domain of ethical/moral leadership [44]. Ethical/moral leadership is an emerging domain of leadership theory built on the foundations of behavioral and follower-centric leadership theories [43,44].

The effect of leadership practices influencing ethical values in the organization has emerged as an integrating framework that explains, to some degree, the relationship between leadership and ethics [14,24]. This line of inquiry has been targeting managers' ethical values, resulting in empirical evidence that leadership practices and ethics are connected [45]. Empirical results confirm that elements of the business environment—such as corruption—are strongly influenced by business managers' practices and attitudes [40]. 


\subsection{Context Specific Leadership Theories in Central Europe}

The Central European Visegrád countries (Czech Republic, Hungary, Poland, and Slovakia) have been known for their unique character, particularly considering the post-transitional contexts [46], compared to other established market economies. Researchers such as Hofstede [47], Laurent [48], and Trompenaars [49] found that diverse management practices are effective and acceptable in different countries. The GLOBE study extended beyond cultural comparison and investigated dimensions of leadership behaviors with the intent of developing country-specific profiles [50]. House et al. [51] collected GLOBE data in 62 countries, including Hungary and Poland (later the Czech Republic was added, but not Slovakia), constructing national profiles and global clusters of leadership and culture relevant to the Visegrád countries. The Eastern Europe cluster (also containing Albania, Georgia, Greece, Hungary, Kazakhstan, Poland, Russia, and Slovenia) of the GLOBE study was primarily characterized by the shared pre-Soviet history, communism, and a strong force of predominantly Asian culture, revealing that societies of the Balkans, Central Europe, Eastern Europe, and Central Asia share substantial similarities [51].

It is within the context of this Central and Eastern European cluster, that an appropriate leadership model was sought to capture follower and leader perspectives on ethical values and practices. There is a conceptual hegemony of 'Western' cross-cultural comparative models addressing culturally contingent leadership theory [52]. Scholars have addressed the necessity of starting culturally specific leadership research by identifying major shortcomings of previously accepted research frameworks [53]. This has particularly been emphasized to accommodate constant shifts and changes, end paradoxical ambiguities, eliminating the possibility of generalizing leadership characteristics into universals in specific cultural contexts [54].

The GLOBE study identifies six universal leadership dimensions, creating the framework of 'culturally endorsed implicit leadership theories' (CLTs) [51]. Jepson [55] argues, that a more dynamic understanding of the dimensionality of leadership is needed, allowing for capturing differences between countries and cultures. The use of universal dimensions is argued against [56], and these dimensions are often misused to draw inaccurate conclusions [57]. A unifying yet flexible framework was sought for within the four Central European Visegrád countries [58].

Scientific management theories have been used in Central European literature [59]. Western management theories have been accepted, translated, and adopted in the Central European context, also discussing leadership theory [60-62]. Successful attempts—such as the Global Executive Leadership Inventory [63] —encompass leaders in both 'Eastern' and 'Western' cultural contexts, while others articulate the need for using Eastern leader attributes [64].

Managers from Central Europe may be more preoccupied with the immediate and challenging daily demands of ongoing transition to a market economy [65]. For example, Polish managers' awareness of leadership culture has only been growing recently, as a driver of business performance [66], and there is a growing number of leadership culture studies in Poland [61], as well as in other Eastern bloc countries. For example, post-transitional Russian leaders distinctively displayed Eastern characteristics of leadership culture [63]. Bakacsi et al. [67] provide a detailed overview of the background, historical and political character of the Central and Eastern European cultural group in the GLOBE leadership study. Corresponding to the Eastern influences [63,64,67], a strong collectivistic flavor with substantial team orientation and a preference for charismatic and participative leadership style was identified, with a uniquely configured power-culture and higher than expected uncertainty accommodating capacity in a traditionally collectivistic context.

\subsection{The Institutional Environment for Doing Business in Central Europe}

North [3] defines institutions as the rules shaping behaviors and interactions between members of a society. These institutions evolve over time, changing the behaviors of economic actors [68]. The change of institutions in turn will shape the behaviors of the actors [4], in particular the practices of business decision makers within an economy [69]. 
Kornai [70] highlights that ethical values are found to be relatively low priority in terms of public debate in the Central European Visegrád countries (Czech Republic, Hungary, Poland, and Slovakia), despite that ethical values have been identified as the baseline for building social institutions [71]. There are obstacles in the business environment of these countries reflected by the rankings of the Doing Business Report [72], the Corruption Perception Index annual report of Transparency International [73] and the Worldwide Governance Indicators [74]. These obstacles are reflected in literature, documenting institutional issues in business across the post-transitional region of Europe [75]. For example, Norris [76] asserts that trust is substantially lower in the Visegrád countries compared to Western countries of the EU.

Various dimensions of the quality of institutional configurations are measurable. The Worldwide Governance Indicators [74] operationalize measures of institutional quality by assessing the performance of the institutional framework in six dimensions: voice and accountability, political; stability and absence of violence/terrorism; government effectiveness; regulatory quality; rule of law; and control of corruption. The Transparency International [73] Corruption Perception Index captures one important aspect of institutional performance globally. The Doing Business Indicators of World Bank [72] expand this spectrum by introducing a wider range of measurable performance indicators, from the perspective of businesses: ease of doing business; starting a business; dealing with construction permits; getting electricity, registering property; getting credit; protecting investors; paying taxes; trading across borders; and enforcing contracts. Figure 1 shows comparative figures of the Worldwide Governance Indicators, highlighting shortfalls of government performance in terms of control of corruption, rule of law, and voice and accountability [74].

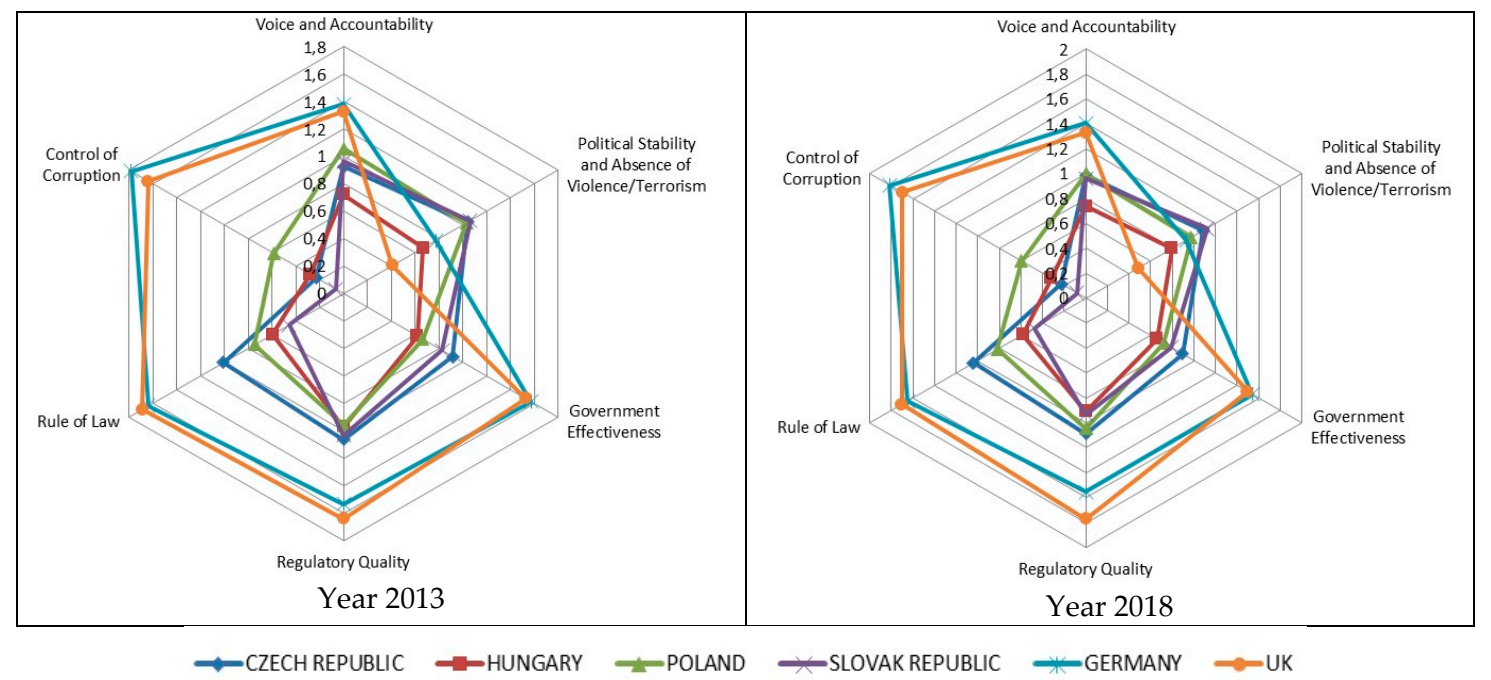

Figure 1. Worldwide Governance Indicators in Central Europe. Notes: (1) Worldwide Governance Indicators are displayed on a scale of -2.5 to +2.5 , a higher score displaying better performance. (2) Germany and the UK are included in the figure as a developed country benchmark. (3) own figure based on data extracted from the World Governance Indicators [74] database.

Corruption Perception Index calculations [73] show presence of corruption in both the private and the public sectors (see Figure 2). The impact of these factors on the business environments of the Central European Visegrád countries is substantial, signified by the Doing Business Indicators [72], displayed in Figure 3. The latest available information (2018) and the figures from the time of conducting the field work (2013) are presented side by side for illustration. Figures 1-3 contain Germany and the UK as reference points, often viewed as a comparative benchmark in terms of institutional and economic performance in Europe. 


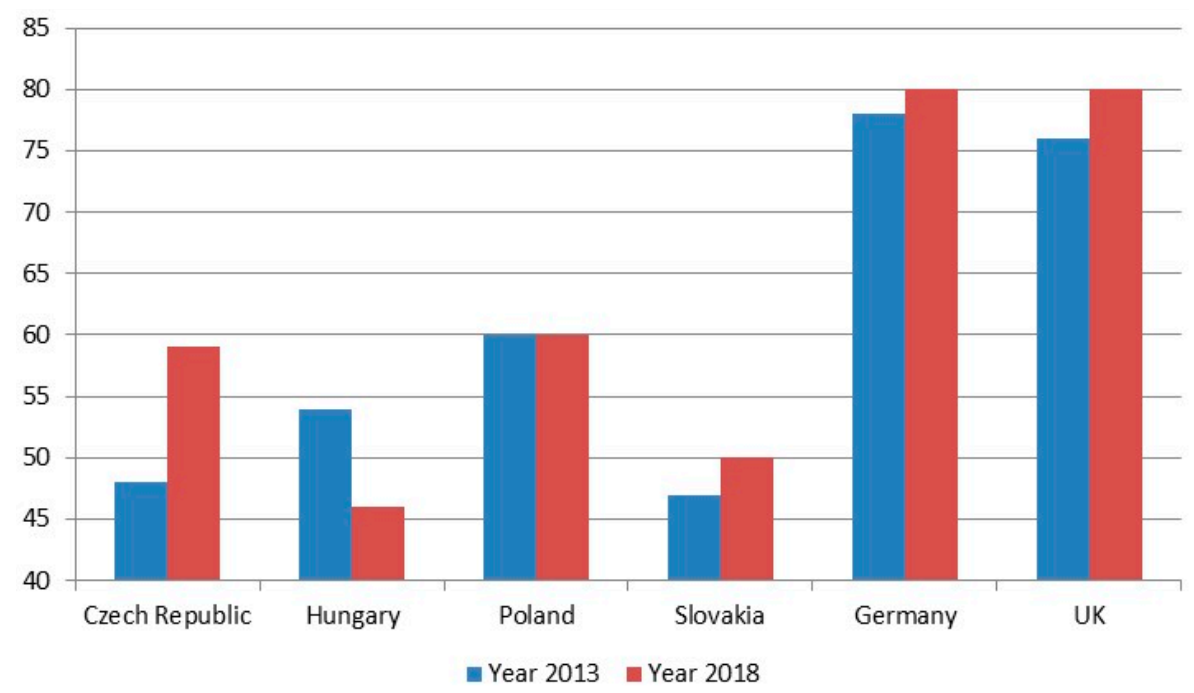

Figure 2. Worldwide Governance Indicators in Central Europe. Notes: (1) Corruption Perception Index scores are displayed on a scale of 0 to 100 , a higher score displaying better performance. (2) Germany and the UK are included in the figure as a developed country benchmark. (3) own figure based on data extracted from Transparency International [73].

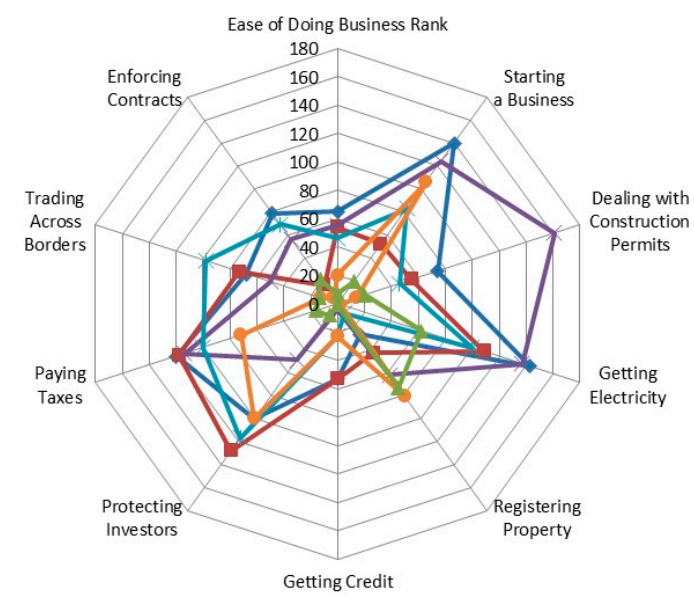

Year 2013 (rank)

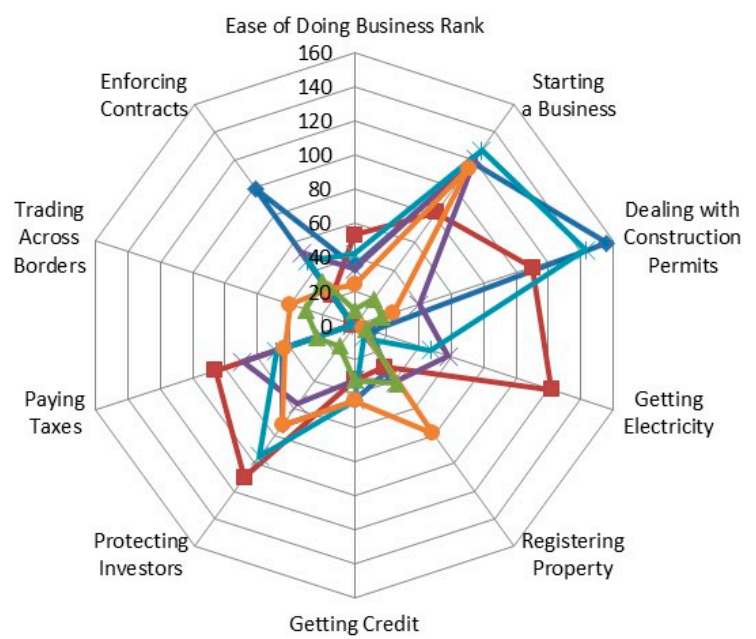

Year 2019 (rank)

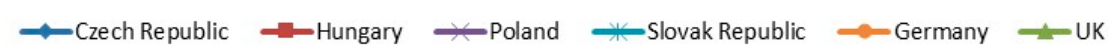

Figure 3. Doing Business in Central Europe. Notes: (1) Doing Business indicator ranks are displayed out of 189 countries. (2) Germany and the UK are included in the figure as a developed country benchmark. (3) own figure based on data extracted from the World Bank [72] Doing Business Reports.

The institutional economics framework conceptually links these aggregate performance measures to individual values and behaviors. Within the context of individual values and behaviors, culture presents itself as an overarching descriptive framework. The following section continues with introducing the domains of leadership and ethics, as the individual level manifestations of institutional quality. We identify a leadership model to be used, that is not only nouvelle in the geographical and institutional context, but is also holistic in the sense that it captures leadership traits, action, context, and values across all generations of leadership theory development. We also discuss ethical values, as part of the model, providing a proxy of institutional quality at an individual level. 


\subsection{Conceptual Model and Hypotheses}

Leadership models incorporating an Eastern contextualization have not yet been applied in Central Europe, even though such models promise a good contextual fit, compared to Western models (such as GLOBE). The Asian Perspectives on Excellence in Leadership (APEL) framework [77] based on both Eastern and Western management literature [78] is used in this paper. The APEL model consists of five behavioral categories: (1) environmental influences, (2) managerial behaviors, (3) organizational demands, (4) personal qualities, and (5) attributes of the excellent leader. Selvarajah et al. ([77] pp. 35-38) defines these categories:

- "Environmental influences are factors outside the organization that have influence on the operation and success of the organization;

- Managerial behavior refers to the values, attitudes, actions, and styles of managers that are specific to the performance of the management task;

- Organizational demands relate to the way a manager reacts or responds to organizational goals, roles, rules, structures, demands, pressures, and rewards;

- Personal qualities refers to the personal values, skills, beliefs, attitudes, and behaviors of the manager, irrespective of profession or organization."

- Leadership excellence is an aggregate category encompassing behaviors generally applicable to multiple or all above mentioned categories.

The APEL model proposes a multi-dimensional view encompassing leadership, in terms of the different generations of leadership theories [35]. The model aligns with the first generation view of leadership theories focusing on traits, in terms of addressing leadership as personal characteristics. The APEL model also incorporates second generation leadership theories with their focus on actions, through its dimension of managerial behaviors. Third generation leadership theories address the context in which leadership takes place through the APEL dimensions of environmental influences and organizational demands. Finally, leadership values that are in the forefront of fourth generation leadership theories are represented in the APEL model by the dimension of leadership excellence. Therefore, the application of the APEL model gives an opportunity to not only explore the relationship between leadership practices and ethical values in a unique cultural context, but also provides an avenue to test the understanding behind the evolution of leadership theory, and its ability to address the ethical question.

Previous implementations of the APEL model have found 37 to 60 different behaviors describing dimensions within the five behavioral categories, in a wide range of Asian countries [78-86], in Europe [87], and in Africa [88]. In this study, the APEL framework was extended to include ethical values as highlighted in Figure 4 to examine the relationship between leadership practices and ethical values of managers from the Central European Visegrád nations. A conceptualization of ethical values relating to corruption [40], governance [41], and transparency [30,42] was developed to integrate with the model of leadership practices.

Theories of ethical leadership suggest a strong link between leadership behaviors and ethical values $[18,20]$. Based on this conceptual framework, and the extensive review of empirical research results of leadership theories presented by Ko et al. [14], the hypotheses are formulated. Empirical evidence is presented that leadership traits (first generation leadership theory) are positively linked with organizational outcomes [35]. This provides a basis for our first hypothesis: 


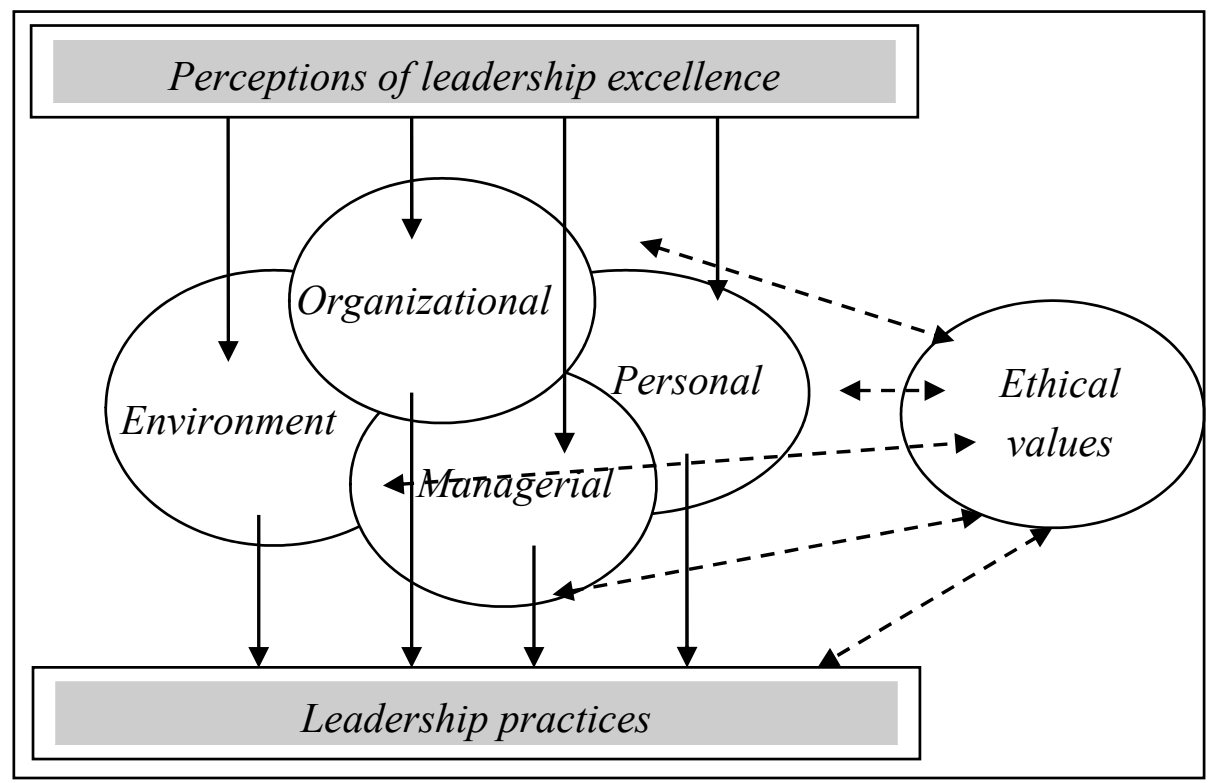

Figure 4. Conceptual framework linking ethics to leadership culture using the APEL model. Figure adapted from Selvarajah et al. [77] by the authors.

Hypothesis 1: Personal qualities are positively associated to ethical values.

Further empirical evidence exists for the positive relationship between leadership actions and organizational outcomes (second generation leadership theories), allowing the formulation of our second hypothesis [35]:

Hypothesis 2: Managerial behaviors are positively associated to ethical values.

Thirdly, evidence is presented for a positive relationship between leadership context and organizational outcomes (third generation leadership theories), supporting the next hypotheses:

Hypothesis 3a: Environmental influences are positively associated to ethical values.

Hypothesis 3b: Organizational demands are positively associated to ethical values.

Finally, leadership values according to ethical leadership theory are expected [14] and have been found to [35] be positively related to ethical values, providing support to our last hypothesis:

Hypothesis 4: Leadership excellence is positively associated to ethical values.

\section{Data Collection and Analysis}

In order to explore the two research propositions, data were collected and analyzed on individual attitudes towards leadership practices and ethical values. In the following sections, details of the data collection, the analytical process, and its results are introduced.

\subsection{Questionnaire Development}

The APEL questionnaire consisting of 94 items for measuring leadership excellence through behaviors was developed by Selvarajah et al. [77] and validated in Asia: Malaysia [79,80], China [81], Singapore [86], Vietnam [83], Cambodia [82], Thailand [89], and trialed in Europe, in the Netherlands [87] and trialed in Africa, in South Africa [88]. Comprehensive analysis of the results was conducted for 
selected ASEAN (Association of Southeast Asian Nations) countries by Taormina and Selvarajah [78], confirming the applicability of the four broad categories identified in the APEL model. Measures of three dimensions of ethical values: corruption [40], governance [16], and transparency [30,42], were adopted from extant literature. These dimensions were selected to align with the aggregate measures of institutional quality, namely governance, corruption, and ease of doing business. Altogether, 14 items measuring the three factors of ethical attitudes were included in the survey. (The authors can provide the details of the full questionnaire upon request.)

Demographic information in relation to respondents—such as age, employment position, sector, and industry-was also collected, to control for biases and representativeness of the data. To ensure accurate representation and communication of concepts in the survey, and the compatibility of the data collected, the questionnaire was translated and subsequently back-translated from all four languages to English [90,91].

\subsection{Data Collection}

Researchers collected 220 responses in the Czech Republic, 201 in Hungary, 220 in Slovakia, and 227 in Poland, totalling 868 responses from the four countries, using a combination of paper-based questionnaires and online surveys, during 2013. The researchers received research ethics approval from Swinburne University of Technology, based on the ethical research code of conduct of the respective institutions, the authors were affiliated with. A key consideration during the data collection was to maintain anonymity of the respondents, and to avoid coercion of respondents.

The researchers approached Czech managers from companies, NGOs (Non-Government Organisations), and the government sector in person. Five hundred and fifty questionnaires were distributed to managers in local companies in the Zlin region, executive level government officials, and Masters students enrolled in the institution working full time, yielding 210 responses, resulting in a $38.2 \%$ response rate. Data collection in Hungary was conducted by distributing the survey to MBA students of the Budapest University of Technology (working full time), and circulated among selected members of the Hungarian Economic Association holding management positions. Seven hundred and seventy-nine survey invitations yielded 201 responses, resulting in a $25.8 \%$ response rate. The Polish researchers administered 662 invitations to potential respondents employed in managerial positions in businesses, government bodies, and NGOs, yielding 227 responses, resulting in a response rate of $34.3 \%$. Three hundred private and public sector managers were randomly selected and contacted in Slovakia, yielding 220 responses, resulting in a response rate of $73.3 \%$.

The tables presented in Appendix A display the response numbers and key demographic characteristics of respondents (labor market participants). In the Czech sample, there are slightly more female respondents. Median age of the respondent population is 35 , which indicates substantial presence of the post-transition generation. Male respondents are also slightly over-represented in the Hungarian sample, with a relatively high proportion of government employees in comparison to other country samples. The median age of respondents in Hungary is 45 , showing that the younger generation is under-represented in the sample compared to the other three country samples. Managers from NGOs are better represented in the Polish sample compared to the other three country samples. Median age of the respondents is between 35 and 45 . There are also slightly more male respondents in the Slovak sample, with high representation of respondents in government positions similar to Hungary. There were no respondents in the NGOs category. Median age of the respondents is between 35 and 45 years.

\subsection{Measurement Validation}

Exploratory factor analysis was conducted to establish common dimensions of the six behavioral categories (leadership excellence, managerial behaviors, organizational demands, environmental influences, personal qualities, and ethical attitudes) conceptualized. Indicators associated with the leadership dimensions were specified based on prior studies utilising the APEL model, to maintain 
face validity. Exploratory factor analysis was used to identify the specific dimensions of the APEL categories, and the ethical conduct category. The indicators associated with the individual behaviors were consolidated into a set of factors measured by the same indicators across all four countries. Factors of leadership and ethical attitudes not present in all four countries as measured by the model were not included in further analysis. This has been done in order to maintain the comparability of the results across the four countries.

The resulting scales were refined and assessed for validity and reliability. Convergent validity was established based on the average variance extracted (AVE) exceeding 0.5 [92]. Reliability was assessed by Cronbach's alpha scores, greater than 0.7 [92]. In certain cases, Cronbach's alpha values greater than 0.6 were also accepted, as suggested by Hair et al. [92] to be suitable for exploratory factor analysis. In cases where the refinement of the measures resulted in scales with less than 3 indicators, Spearman's correlation was used to evaluate the reliability of the two-item scales. Spearman's correlation is appropriate to evaluate the strength of connection between variables measured on a 5-point Likert-type response format, and is reflective of scale reliability in such cases [93]. Highly significant $(p<0.01)$ and medium $(0.3<|\rho|<0.5)$ level correlations were sought, but significant $(p<0.05)$ or low $(0.1<|\rho|<0.3)$ level correlations were occasionally also accepted for the exploratory analysis [93]. In general, the results are further validated by deriving a similar factor structure and scale composition across all four countries.

After assessing the validity and reliability of measures, correlations were explored to quantify the link between ethics and leadership culture, in order to reflect on the hypotheses.

\subsubsection{Leadership Excellence}

This factor in the Visegrád countries presented itself as a single, monolithic leadership dimension. The validity and reliability statistics of the leadership excellence scale are shown in Table 1. (Full scale details are presented in Appendix B). One of the strongest loading variables in all four countries was employee motivation, and one of the weakest was developing competitive strategies. The composition of the leadership excellence dimension was similar to that of the original conceptualization by Selvarajah et al. [83], focusing on a broad range of highly important behaviors practiced by excellent leaders, aligning into a single dimension.

Table 1. Leadership excellence scale.

\begin{tabular}{cccccc}
\hline LEADERSHIP EXCELLENCE & Loadings & & & & \\
\hline Eigenvalue of factor & $\mathrm{CZ}$ & $\mathrm{HU}$ & $\mathrm{SK}$ & $\mathrm{PL}$ & All V4 \\
\hline Cronbach's Alpha & $(2.56)$ & $(2.56)$ & $(2.50)$ & $(2.92)$ & $(2.63)$ \\
\hline Total/Average Variance Extracted (AVE) & 0.75 & 0.76 & 0.74 & 0.80 & 0.76 \\
\hline
\end{tabular}

\subsubsection{Environmental Influences}

The two dimensions identified by the respondents were: (1) cultural tolerance and (2) environmental awareness and screening, as displayed in Table 2. (Full scale details are presented in Appendix B). In cultural tolerance, multicultural orientation was commonly understood was the strongest loading item. Environmental awareness and screening was characterized by technology awareness and screening for problems and opportunities.

Reliability of the cultural tolerance scale for the Czech sample was weaker (Cronbach's alpha $<0.7$ ), but this finding is not unusual. The GLOBE results have also encountered issues with the factor analysis for Czech empirical results [64]. 
Table 2. Environmental influences scales.

\begin{tabular}{|c|c|c|c|c|c|}
\hline \multirow{2}{*}{$\begin{array}{c}\text { ENVIRONMENTAL INFLUENCES } \\
\text { CULTURAL TOLERANCE }\end{array}$} & \multicolumn{5}{|c|}{ Loadings } \\
\hline & $\mathrm{CZ}$ & HU & SK & PL & All V4 \\
\hline Eigenvalue of factor & $(2.23)$ & $(2.68)$ & $(2.74)$ & $(2.97)$ & $(2.70)$ \\
\hline Cronbach's Alpha & 0.69 & 0.74 & 0.77 & 0.79 & 0.76 \\
\hline Average Variance Extracted (AVE) & 0.51 & 0.53 & 0.55 & 0.58 & 0.55 \\
\hline $\begin{array}{l}\text { ENVIRONMENTAL AWARENESS } \\
\text { and SCREENING }\end{array}$ & $\mathrm{CZ}$ & HU & SK & PL & All V4 \\
\hline Eigenvalue of factor & $(1.45)$ & $(1.05)$ & $(1.25)$ & $(1.15)$ & $(1.18)$ \\
\hline Spearman's correlation & $0.45^{* *}$ & $0.42 * *$ & $0.57^{* *}$ & $0.60 * *$ & $0.51^{* *}$ \\
\hline Average Variance Extracted & 0.67 & 0.66 & 0.76 & 0.76 & 0.72 \\
\hline Total Variance Extracted (by all factors) & $61.2 \%$ & $62.1 \%$ & $66.4 \%$ & $68.7 \%$ & $64.6 \%$ \\
\hline
\end{tabular}

\subsubsection{Managerial Behaviors}

It was difficult to identify the commonalities across the various countries in this category. Eventually, the dimensions of (1) practicality, (2) teamwork, and (3) decisiveness were identified, as shown in Table 3. (Full scale details are presented in Appendix B). In terms of practicality, task focus loaded strongest for Czech, Slovak, and Polish managers, while detail orientation loaded strongest for Hungarian managers. Allowing subordinates autonomy was the strongest loading indicator of the teamwork dimension in all countries. Speed of decision making was the strongest loading indicator of the decisiveness factor in all samples. The Hungarian and Czech samples stand out in terms of the practicality dimension, the Czech sample for teamwork, the Czech, Hungarian, and Slovak samples for decisiveness, which unfortunately show weaker reliability, reflecting the difficulty to cross-validate a common factor structure across the four countries.

Table 3. Managerial behaviors scales.

\begin{tabular}{cccccc}
\hline MANAGERIAL BEHAVIORS & \multicolumn{5}{c}{ Loadings } \\
\hline PRACTICALITY & CZ & HU & SK & PL & All V4 \\
\hline Eigenvalue of factor & $(1.04)$ & $(1.46)$ & $(1.35)$ & $(0.87)$ & $(0.94)$ \\
\hline $\begin{array}{c}\text { Focus on the task-in-hand } \\
\text { Think about the specific details of any } \\
\text { particular problem }\end{array}$ & 0.73 & 0.74 & 0.88 & 0.84 & 0.87 \\
\hline $\begin{array}{c}\text { Spearman's correlation } \\
\text { Average Variance Extracted (AVE) }\end{array}$ & 0.71 & 0.78 & 0.76 & 0.73 & 0.68 \\
\hline TEAMWORK & 0.52 & 0.58 & 0.65 & 0.62 & 0.61 \\
\hline Eigenvalue of factor & $\mathbf{C Z}$ & $\mathbf{H U}$ & $\mathbf{S K}$ & PL & All V4 \\
\hline Allow subordinates authority and autonomy & 0.83 & 0.83 & 0.82 & 0.86 & 0.84 \\
\hline Consider suggestions made by employees & 0.64 & 0.73 & 0.79 & 0.77 & 0.75 \\
\hline Spearman's correlation & $0.16^{*}$ & $0.33^{* *}$ & $0.34 * *$ & $0.41^{* *}$ & $0.36^{* *}$ \\
\hline Average Variance Extracted $(A V E)$ & 0.55 & 0.62 & 0.65 & 0.67 & 0.63 \\
\hline
\end{tabular}


Table 3. Cont.

\begin{tabular}{cccccc}
\hline MANAGERIAL BEHAVIORS & \multicolumn{5}{c}{ Loadings } \\
\hline DECISIVENESS & CZ & HU & SK & PL & All V4 \\
\hline Eigenvalue of factor & $(2.41)$ & $(2.20)$ & $(2.25)$ & $(2.62)$ & $(2.40)$ \\
\hline Make work decisions quickly & 0.87 & 0.83 & 0.81 & 0.82 & 0.81 \\
\hline $\begin{array}{c}\text { Make decisions earlier rather than later } \\
\text { Make decisions without depending too much } \\
\text { on others }\end{array}$ & 0.73 & 0.66 & 0.57 & 0.71 & 0.66 \\
\hline $\begin{array}{c}\text { Cronbach's Alpha } \\
\text { Average Variance Extracted (AVE) }\end{array}$ & 0.68 & 0.73 & 0.85 & 0.82 & 0.80 \\
\hline Total Variance Extracted (by all factors) & $62.9 \%$ & $65.5 \%$ & $66.7 \%$ & $69.4 \%$ & $66.1 \%$ \\
\hline
\end{tabular}

\subsubsection{Organizational Demands}

Organizational demands form one dimension in the study across all four countries (shown in Table 4). (Full scale details are presented in Appendix B). The strongest loading component of this dimension of leadership in the Czech, Slovak, and Polish sample was the support for joint decisions, and advocating a professional image in the Hungarian context. Despite further efforts of attempting to refine this scale to maintain reliability and validity, the psychometric qualities of this scale did not meet the minimum requirements, and therefore it was not possible to utilize this part of the data collected for further analysis.

Table 4. Organizational demands scale.

\begin{tabular}{cccccc}
\hline ORGANIZATIONAL DEMANDS & Loadings & & & & \\
\hline Eigenvalue of factor & $\mathrm{CZ}$ & $\mathrm{HU}$ & $\mathrm{SK}$ & $\mathrm{PL}$ & All V4 \\
\hline Act as a member of a team & $(1.71)$ & $(1.44)$ & $(1.58)$ & $(1.70)$ & $(1.61)$ \\
\hline $\begin{array}{c}\text { Support decisions made jointly by others } \\
\text { Sell the professional image or corporate image } \\
\text { to the public }\end{array}$ & 0.76 & 0.65 & 0.74 & 0.72 & 0.74 \\
\hline Cronbach's Alpha & 0.72 & 0.77 & 0.66 & 0.71 & 0.69 \\
\hline Total/Average Variance Extracted (AVE) & $57.1 \%$ & $48.1 \%$ & $52.8 \%$ & $56.7 \%$ & $53.7 \%$ \\
\hline
\end{tabular}

\subsubsection{Personal Qualities}

This dimension has also displayed substantial diversity among the different countries, but eventually, substantial commonalities were identified as displayed in Table 5. (Full scale details are presented in Appendix B). The two dimensions found in this category are (1) openness and (2) moral virtue. Openness refers to consistency and accountability, and moral virtue stands for moral and emotional drive.

Being consistent is the common and strongest loading shared value across the Polish and Slovak samples, while in the Czech and Hungarian samples, accountability was the strongest determinant of openness. Emotional considerations loaded the strongest in Czech, Hungarian, and Polish samples, in terms of virtue, while morals loaded strongest in the Slovak sample.

The reliability of the openness scale for the Slovak data is relatively low, similar to the reliability of the moral virtue scale for the Hungarian sample, showing some minor issues with the scales used. 
Table 5. Measures of personal qualities.

\begin{tabular}{cccccc}
\hline PERSONAL QUALITIES & \multicolumn{5}{c}{ Loadings } \\
\hline OPENNESS & CZ & HU & SK & PL & All V4 \\
\hline Eigenvalue of factor & $(1.78)$ & $(1.55)$ & $(1.05)$ & $(1.71)$ & $(1.71)$ \\
\hline Spearman's correlation & $0.51^{* *}$ & $0.39^{* *}$ & $0.24^{* *}$ & $0.41^{* *}$ & $0.39^{* *}$ \\
\hline Average Variance Extracted (AVE) & 0.77 & 0.64 & 0.62 & 0.73 & 0.71 \\
\hline MORAL VIRTUE & CZ & HU & SK & PL & All V4 \\
\hline Eigenvalue of factor & $(1.22)$ & $(1.16)$ & $(1.72)$ & $(1.28)$ & $(1.65)$ \\
\hline Spearman's correlation & $0.43^{* *}$ & $0.30 * *$ & $0.48^{* *}$ & $0.43^{* *}$ & $0.41^{* *}$ \\
\hline Average Variance Extracted (AVE) & 0.71 & 0.65 & 0.73 & 0.72 & 0.71 \\
\hline Total Variance Extracted (by all factors) & $75.0 \%$ & $67.6 \%$ & $69.1 \%$ & $74.7 \%$ & $71.9 \%$ \\
\hline
\end{tabular}

\subsubsection{Ethical Values}

Table 6 displays the two dimensions of ethical values as measured in the survey. (Full scale details are presented in Appendix B). The conceptualization of ethical dimensions suggested three dimensions: corruption, governance, and transparency. However, these three dimensions were not reflected in the results of the factor analyses. A two-factor solution was selected, identifying positive and negative attitudes in relation to ethical conduct, which is to the findings of Resick et al. [30]. The two-factor solution, explained by Resick et al. [30], occurs when respondents distinguish between positive and negative behavioral patterns in terms of ethical attitudes, but do not express different attitudes towards specific areas of ethical conduct. Differences are identifiable between the different countries in terms of loadings of various indicators compared to each other. While accepting corruption as part of doing business was the strongest loading indicators of negative behavioral patterns across all countries, the neglect of accountability and transparency was the weakest loading indicator.

Table 6. Ethical values scales.

\begin{tabular}{cccccc}
\hline NEGATIVE PATTERNS & CZ & HU & SK & PL & All V4 \\
\hline Eigenvalue of factor & $(3.99)$ & $(3.90)$ & $(3.89)$ & $(3.13)$ & $(3.38)$ \\
\hline Cronbach's Alpha & 0.86 & 0.90 & 0.89 & 0.82 & 0.86 \\
\hline Average Variance Extracted (AVE) & 0.59 & 0.69 & 0.65 & 0.52 & 0.59 \\
\hline POSITIVE PATTERNS & CZ & HU & SK & PL & All V4 \\
\hline Eigenvalue of factor & $(2.08)$ & $(1.79)$ & $(2.76)$ & $(2.84)$ & $(2.26)$ \\
\hline Cronbach's Alpha & 0.73 & 0.79 & 0.85 & 0.86 & 0.74 \\
\hline Average Variance Extracted (AVE) & 0.54 & 0.62 & 0.69 & 0.69 & 0.56 \\
\hline
\end{tabular}

In terms of positive patterns, consulting stakeholders was the weakest loading component of good practice for the Czech, Slovak, and Polish respondents. Considerations for stakeholder impact loaded the strongest item for Czech respondents, while assessing stakeholder claims loaded the strongest in the case of the Hungarian, Slovak, and Polish samples.

\subsubsection{Discriminant Validity}

Discriminant validity was assessed using the Fornell and Larcker [94] criterion. According to the results displayed in Table 7, all dimensions are compliant, however as the organizational demands category of the APEL model lacked convergent validity and reliability, it was not included in further 
analysis. Therefore, the relationships between the organizational demands category and the dimensions of ethical attitudes were not evaluated.

Table 7. Discriminant validity evaluation for the combined sample.

\begin{tabular}{|c|c|c|c|c|c|c|c|c|c|c|c|}
\hline Categories & Dimensions & (1) & (2) & (3) & (4) & (5) & (6) & (7) & $(8)$ & (9) & (10) \\
\hline \multirow{2}{*}{ Ethical Values } & Negative patterns (1) & 0.78 & & & & & & & & & \\
\hline & Positive patterns (2) & $0.07 *$ & 0.81 & & & & & & & & \\
\hline \multicolumn{2}{|c|}{ Leadership Excellence (3) } & $-0.24 * *$ & $0.33^{* *}$ & 0.72 & & & & & & & \\
\hline \multirow[b]{2}{*}{$\begin{array}{l}\text { Environ-mental } \\
\text { Influences }\end{array}$} & Cultural tolerance (4) & -0.07 & $0.26^{* *}$ & $0.49^{* *}$ & 0.74 & & & & & & \\
\hline & $\begin{array}{c}\text { Environmental } \\
\text { Awareness and } \\
\text { Screening (5) }\end{array}$ & $-0.08 *$ & $0.22 * *$ & $0.51^{* *}$ & $0.36^{* *}$ & 0.85 & & & & & \\
\hline \multirow{3}{*}{$\begin{array}{c}\text { Managerial } \\
\text { Behaviors }\end{array}$} & Practicality (6) & -0.05 & $0.11^{* *}$ & $0.39 * *$ & $0.31^{* *}$ & $0.37 * *$ & 0.79 & & & & \\
\hline & Teamwork (7) & $-0.24 * *$ & $0.21 * *$ & $0.50 * *$ & $0.38^{* *}$ & $0.30 * *$ & $0.23 * *$ & 0.82 & & & \\
\hline & Decisiveness (8) & -0.02 & $0.08 *$ & $0.38^{* *}$ & $0.31 * *$ & $0.38 * *$ & $0.37 * *$ & $0.19 * *$ & 0.78 & & \\
\hline \multirow{2}{*}{$\begin{array}{l}\text { Personal } \\
\text { Qualities }\end{array}$} & Openness (9) & $-0.13^{* *}$ & $0.14^{* *}$ & $0.40^{* *}$ & $0.31 * *$ & $0.22 * *$ & $0.33 * *$ & $0.30 * *$ & $0.28 * *$ & 0.84 & \\
\hline & Virtue (10) & $0.07^{*}$ & 0.01 & $0.15^{* *}$ & $0.30^{* *}$ & $0.17^{* *}$ & $0.15^{* * *}$ & $0.21 * *$ & $0.11^{* * *}$ & $-0.13^{* *}$ & 0.84 \\
\hline
\end{tabular}

${ }^{*}$ significant at $p<0.05,{ }^{* *}$ significant at $p<0.01$, The diagonal of the table contains the squared root of AVE score for each dimension [94].

\subsection{Exploring the Relationship between Leadership and Ethics}

After establishing validity and reliability of the scales used in measuring leadership behaviors and ethical attitudes, mean scores of the scales were calculated to explore the relationships between the constructs. Correlation analysis was used to reveal the relationships between the categories in the leadership model and dimensions of ethical attitudes of the respondents.

\subsubsection{Descriptive Statistics}

Table 8 provides detail on means and standard deviations of responses. Country scores above the four-country average are highlighted in bold. Standard deviation displays the discrepancies between respondents within the sample. The standard deviation values in the dimensions on which the respondents expressed opinions the least consistently, were marked in italics.

It appears that Hungarian response means are most frequently the highest, indicating potential presence of some biasing effect (such as social desirability). At the same time, the Slovak sample shows the lowest level of consistency (highest standard deviation) amongst the respondents in the four APEL categories and ethical values, followed by the Polish sample, suggesting that the opinions of the respondents varied the most in these two countries. On the other hand, the respondents from Hungary and the Czech Republic were more consistent in their expressed values and opinions.

\subsubsection{Correlation Analysis}

A bivariate Pearson's correlation matrix is used to assess relationships between categories of leadership excellence, and ethical attitudes. Table 9 underpins a broadly positive relationship between leadership excellence and attitudes towards the positive ethical dimension. The leadership excellence category and both dimensions of environmental influences show significant positive relationships to positive ethical attitudes in all four Visegrád countries.

Data provides varying outcomes regarding the dimension of managerial behaviors and personal qualities. For example, virtue, incorporating issues of morality, only relate to positive ethical attitudes in case of the Slovak sample. However, the relationships are not consistent across the board for the managerial behaviors dimension either, suggesting that this aspect of leadership excellence is not universally related to ethical behavior. 
Table 8. Response statistics for leadership practices and ethical values.

\begin{tabular}{|c|c|c|c|c|c|c|c|}
\hline & & & $\mathrm{CZ}$ & HU & PL & SK & \multirow{2}{*}{ V4 MEAN } \\
\hline \multicolumn{3}{|c|}{ N (Number of Respondents per Country) } & 220 & 201 & 227 & 220 & \\
\hline \multirow{4}{*}{$\begin{array}{l}\text { Ethical } \\
\text { values }\end{array}$} & \multirow{2}{*}{ Negative Patterns } & Mean & 2.01 & 2.02 & 1.66 & 1.97 & \multirow{2}{*}{1.91} \\
\hline & & Std. dev. & 0.84 & 1.06 & 0.69 & 0.92 & \\
\hline & \multirow{2}{*}{ Positive Patterns } & Mean & 3.07 & 3.37 & 3.57 & 3.19 & \multirow{2}{*}{3.30} \\
\hline & & Std. dev. & 0.73 & 0.86 & 0.96 & 0.88 & \\
\hline \multirow{2}{*}{\multicolumn{2}{|c|}{ Leadership Excellence }} & Mean & 4.10 & 4.33 & 4.11 & 4.08 & \multirow{2}{*}{4.15} \\
\hline & & Std. dev. & 0.63 & 0.57 & 0.72 & 0.69 & \\
\hline \multirow{4}{*}{$\begin{array}{l}\text { Environmental } \\
\text { Influences }\end{array}$} & \multirow{2}{*}{$\begin{array}{l}\text { Cultural } \\
\text { Tolerance }\end{array}$} & Mean & 3.23 & 3.66 & 3.43 & 3.31 & \multirow{2}{*}{3.40} \\
\hline & & Std. dev. & 0.73 & 0.81 & 0.86 & 0.88 & \\
\hline & \multirow{2}{*}{$\begin{array}{c}\text { Environmental } \\
\text { Awareness and Screening }\end{array}$} & Mean & 3.71 & 4.11 & 3.85 & 4.01 & \multirow{2}{*}{3.91} \\
\hline & & Std. dev. & 0.80 & 0.75 & 0.88 & 0.92 & \\
\hline \multirow{6}{*}{$\begin{array}{l}\text { Managerial } \\
\text { Behaviors }\end{array}$} & \multirow{2}{*}{ Practicality } & Mean & 3.84 & 4.08 & 3.87 & 3.77 & \multirow{2}{*}{3.88} \\
\hline & & Std. dev. & 0.67 & 0.67 & 0.77 & 0.88 & \\
\hline & \multirow{2}{*}{ Teamwork } & Mean & 3.45 & 4.14 & 3.99 & 3.64 & \multirow{2}{*}{3.80} \\
\hline & & Std. dev. & 0.71 & 0.67 & 0.78 & 0.78 & \\
\hline & \multirow{2}{*}{ Decisiveness } & Mean & 3.66 & 3.94 & 3.61 & 3.74 & \multirow{2}{*}{3.69} \\
\hline & & Std. dev. & 0.74 & 0.66 & 0.74 & 0.77 & \\
\hline \multirow{4}{*}{$\begin{array}{l}\text { Personal } \\
\text { Qualities }\end{array}$} & \multirow{2}{*}{ Openness } & Mean & 4.37 & 4.60 & 4.04 & 3.36 & \multirow{2}{*}{4.08} \\
\hline & & Std. dev. & 0.81 & 0.53 & 0.79 & 0.74 & \\
\hline & \multirow{2}{*}{ Virtue } & Mean & 2.27 & 2.85 & 2.77 & 3.56 & \multirow{2}{*}{2.96} \\
\hline & & Std. dev. & 0.86 & 1.05 & 1.02 & 0.78 & \\
\hline
\end{tabular}

1: strongly disagree; 5 : strongly agree.

Table 9. Correlations between leadership practices and positive ethical attitudes.

\begin{tabular}{|c|c|c|c|c|c|c|}
\hline \multirow{2}{*}{\multicolumn{2}{|c|}{$\begin{array}{c}\text { Leadership Excellence Categories } \\
\text { and Dimensions }\end{array}$}} & \multicolumn{5}{|c|}{ Positive Ethical Attitudes } \\
\hline & & HU & $\mathrm{CZ}$ & SK & PL & All \\
\hline \multicolumn{2}{|c|}{ Leadership excellence } & $\underline{0.25^{* *}}$ & $\underline{0.28^{* *}}$ & $\underline{0.29 * *}$ & $\underline{0.47^{* *}}$ & $\underline{0.33}$ ** \\
\hline \multirow{2}{*}{$\frac{\text { Environmental }}{\underline{\text { Influences }}}$} & Cultural Tolerance & $\underline{0.17^{*}}$ & $\underline{0.29 * *}$ & $\underline{0.30 * *}$ & $\underline{0.22 * *}$ & $0.26^{*}$ \\
\hline & $\begin{array}{l}\text { Environmental } \\
\text { Awareness and Screening }\end{array}$ & $\underline{0.18^{*}}$ & $\underline{0.16^{*}}$ & $\underline{0.18^{* *}}$ & $\underline{0.30 * *}$ & $\underline{0.22}$ ** \\
\hline \multirow{3}{*}{$\begin{array}{l}\text { Managerial } \\
\text { Behaviors }\end{array}$} & Practicality & n.s. & n.s. & n.s. & $0.24^{* *}$ & $0.11^{* *}$ \\
\hline & Teamwork & n.s. & $0.16 *$ & n.s. & $0.23^{* *}$ & $0.21 * *$ \\
\hline & Decisiveness & n.s. & $0.15^{*}$ & n.s. & $0.16 *$ & $0.08 *$ \\
\hline \multirow{2}{*}{$\begin{array}{l}\text { Personal } \\
\text { Qualities }\end{array}$} & Openness & n.s. & n.s. & n.s. & $0.30 * *$ & $0.14^{* *}$ \\
\hline & Moral Virtue & n.s. & n.s. & $0.15 *$ & n.s. & n.s. \\
\hline
\end{tabular}

${ }^{*}$ correlations significant at $p<0.05 ;{ }^{* *}$ correlations significant at $p<0.01 ;$ n.s., correlations not significant.

The relationships between dimensions of leadership excellence and negative ethical attitudes are summarized in Table 10. The leadership excellence category shows significant negative correlation to negative ethical behaviors, demonstrating that respondents in all four countries are well aware that good leadership cannot be executed through unethical behaviors. 
Table 10. Correlations between leadership practices and negative ethical attitudes.

\begin{tabular}{|c|c|c|c|c|c|c|}
\hline \multirow{2}{*}{\multicolumn{2}{|c|}{ Leadership Excellence Categories and Dimensions }} & \multicolumn{5}{|c|}{ Negative Ethical Behaviors } \\
\hline & & HU & $\mathrm{CZ}$ & SK & PL & All \\
\hline \multicolumn{2}{|c|}{ Leadership Excellence } & $-0.21 * *$ & $-0.30 * *$ & $-0.29 * *$ & $-0.23 * *$ & $-0.24 * *$ \\
\hline \multirow{2}{*}{$\begin{array}{l}\text { Environmental } \\
\text { Influences }\end{array}$} & Cultural Tolerance & n.s. & n.s. & n.s. & n.s. & $0.086^{*}$ \\
\hline & $\begin{array}{l}\text { Environmental Awareness } \\
\text { and Screening }\end{array}$ & n.s. & $-0.16^{*}$ & n.s. & $-0.16^{*}$ & -0.08 * \\
\hline \multirow{3}{*}{ Managerial Behaviors } & Practicality & n.s. & $-0.14 *$ & n.s. & n.s. & n.s. \\
\hline & Teamwork & $\underline{-0.42 * *}$ & $\underline{-0.18^{* *}}$ & $-0.16^{*}$ & $-0.23 * *$ & $-0.24^{* *}$ \\
\hline & Decisiveness & n.s. & n.s. & n.s. & $0.14^{*}$ & n.s. \\
\hline \multirow{2}{*}{ Personal Qualities } & Openness & -0.50 ** & $-0.32 * *$ & n.s. & n.s. & $-0.13^{* *}$ \\
\hline & Moral Virtue & $0.32 * *$ & n.s. & -0.25 & n.s. & $0.07^{*}$ \\
\hline
\end{tabular}

${ }^{*}$ correlations significant at $p<0.05 ;{ }^{* *}$ correlations significant at $p<0.01 ; n$.s., correlations not significant.

Cultural tolerance displays no relationship to negative ethical attitudes, interestingly demonstrating that while this dimension significantly relates to positive ethical attitudes, it does carry potential to eliminating bad ethical practices. The dimension of moral virtue-incorporating morality-demonstrates an adverse relationship to negative ethical attitudes, similarly to positive attitudes. The other dimension of the personal qualities category (openness)—defined as a mixture of personal values-is mostly consistently negatively correlated with negative ethical attitudes, indicating the direction of the link between the personal qualities category and negative ethical attitudes. This link is however not reflected in the Slovak and the Polish samples, therefore the link between these dimensions cannot be confirmed.

The teamwork dimension-showing inclusive work practices-of the managerial behaviors category is also consistently negatively related to negative ethical attitudes. The negative relationships of teamwork to negative ethical attitudes in all four countries highlight existing and effective means of potentially combating corruption, and other undesirable ethical practices.

\section{Discussion of Results}

The paper set out to investigate the relationship between leadership practices and ethical values, and evaluate leadership and ethical attitudes in the context of the Central European Visegrád countries. The hypotheses anticipated positive relationships between leadership practices and ethical values. Table 11 provides a summary of the outcomes of hypothesis testing. Hypothesis 1 is not supported because factor of the personal qualities category is significantly related to ethical attitudes in all four countries. Hypothesis 2 is partially supported, because only one dimension of environmental influences (teamwork) is linked significantly, and only to negative ethical attitudes. Hypothesis 3a is only partially supported, because both its dimensions are significantly positively associated to only the positive ethical attitudes, but no significant relationship is demonstrated to the negative ethical attitudes. We were unable to test Hypothesis $3 b$, because it was not possible to validate the organizational demands scale. Finally, hypothesis 4 is fully supported, because leadership excellence is significantly related to both dimensions of ethical attitudes, in an appropriate direction.

These results imply, that in the Visegrád countries, only the fourth stage (values based) leadership model can provide a coherent explanation to ethical leadership, while the other theories only demonstrate a partial link to ethical values. 
Table 11. Correlations between leadership practices and positive ethical attitudes.

\begin{tabular}{|c|c|c|c|}
\hline & & $\begin{array}{c}\text { Positive Ethical } \\
\text { Attitudes }\end{array}$ & $\begin{array}{c}\text { Negative Ethical } \\
\text { Attitudes }\end{array}$ \\
\hline \multirow{2}{*}{ H1: Personal qualities } & Openness & & \\
\hline & Moral Virtue & & \\
\hline \multirow{3}{*}{$\begin{array}{l}\text { H2: Managerial } \\
\text { behaviors }\end{array}$} & Practicality & & \\
\hline & Teamwork & & SUPPORTED \\
\hline & Decisiveness & & \\
\hline \multirow{2}{*}{$\begin{array}{l}\text { H3a: Environmental } \\
\text { influences }\end{array}$} & Cultural Tolerance & SUPPORTED & \\
\hline & $\begin{array}{c}\text { Environmental } \\
\text { Awareness and Screening }\end{array}$ & SUPPORTED & \\
\hline \multicolumn{2}{|c|}{ H4: Leadership excellence } & SUPPORTED & SUPPORTED \\
\hline
\end{tabular}

\subsection{Congruence between Leadership Behaviors and Ethical Attitudes}

As described above (see Table 11), some hypotheses are partially, others are fully supported by the results. The leadership excellence and of the environmental influences categories relate positively to positive ethical attitudes (see Table 10). Characteristics of the leadership excellence category, and the teamwork dimension of the managerial behaviors category display a significant negative correlation to negative ethical attitudes (see Table 11). These results indicate, that while leadership traits, actions, and values (generations two and three of leadership theories) are partially able to explain ethical attitudes of leaders, it is only the value-based leadership theory (generation four), that is able to comprehensively explain both positive and negative ethical attitudes of the respondents.

Specifically, leadership excellence, managerial behaviors, and environmental influences categories of the leadership model are related significantly to ethical attitudes. Teamwork—as a set of managerial behaviors-serves as inhibitor of negative ethical attitudes. Cultural tolerance and environmental awareness and training dimensions of the environmental influences category support positive ethical attitudes. Leadership excellence is significantly positively related to positive, and negatively to negative ethical attitudes, demonstrating the ability of a values based leadership approach to explain ethical leadership the best.

While the results have been able to demonstrate that several dimensions of leadership excellence are positively related to positive and negatively related to negative ethical attitudes across all four Central European Visegrád countries, several leadership dimensions showed no significant relationships with ethics, or only showed a significant relationship in some countries but not others.

In summary, Hypothesis 4 can be supported, because significant relationships have been found demonstrating that a values-based approach to leadership is congruent with ethical values. However, there have been no consistent correlations found between leadership and ethics indicators at the trait, action and context-based approaches [35], providing evidence that a values-based approach to leadership is necessary to explain leadership ethics.

Based on this outcome, it would be logical to assume, that leadership excellence incorporating teamwork, environmental awareness and screening, and cultural tolerance creates an ethical business environment that is corruption free and transparent. However, what is expressed at the micro level-in the form of a coherent system of values-is not necessarily reflected at the macro level, in the business environment. This issue is initially indicated in our discussion regarding the context of the research, and elaborated further in the following section of the discussion.

\subsection{The 'Gap'}

It has been argued, that ethics in leadership follows a trickle-down process, and that leadership ethics has substantial aggregate implications at the business environment level, through influencing 
the ethical conduct of individuals [24,95]. Our results demonstrate that respondents subscribing to certain leadership values (such as leadership excellence) also expressed positive ethical attitudes. This illustrates the first step of the trickle-down effect also evidenced by Harshman and Harshman [23], Ruiz, Ruiz, and Martinez [95], and Mozumder [24]. On the flip side, respondents subscribing to certain other excellent leadership behaviors reject negative ethical attitudes. This illustrates the trickle-down effect, in that leaders do not only have the capability to inspire good conduct in subordinates, but also discourage poor conduct.

With this evidence illustrating the trickle-down effect of ethical leadership, and the congruence of leadership behaviors and ethical attitudes in the Central European Visegrád countries, the necessity presents itself to explain why individual level results showing an ethical approach to leadership are not reflected in the performance of the institutional environment in terms of business conduct and other indicators. Given a positive relationship between leadership practices and ethical values was found, a gap emerges in terms of the individual leadership ethics and the aggregate observations of the business environment as described by the institutional indicators (see Figures 1-3).

Blake [96] describes this gap within the bounds of the theory of planned behavior [97,98], as individual respondents expressing different intent to the measurable outcome of their actions. An aggregate measure of the outcome of the respondents' actions is reflected in the business environment (World Governance Indicators [74], Corruption Perception Index [73], Doing Business Indicators [72]). Therefore, the gap is identified if leadership practices and ethical values are positively related, while the institutional environmental indicators are less favorable. Reversing the argument, the aggregate institutional performance indicators falling short of the benchmark suggest gaps in individual performance (practices and values) of leadership and ethics, implying the presence of a gap.

This value-action gap manifests between micro and macro levels of institutional qualities in the Central European Visegrád countries, and is demonstrated by the difference between individual values and collective outcomes [99]. Positive relationships between leadership behaviors and ethical attitudes would imply a well performing institutional environment. As illustrated by the Corruption Perception Index [73], Doing Business Indicators [72], and the Worldwide Governance Indicators [74]—from the year of the survey data collection (2013) - the performance of the institutional environment was not as strong as the individual level results would suggest. Leadership practices and ethical values are indicative of a good outcome from an individual level, and something else inhibits the positive impact to manifest at the aggregate level. Therefore, it can be concluded, that the institutional environment is not conducive to the sustainable economic development, which could be achievable building on the micro level leadership values.

Potential explanations to this observation may be found in either firm level factors or in the dynamics of the change process of the institutional environment. In the case of Central European countries, institutional transition can be identified in the phenomenon of transition [70,71], that resulted in developing a gap between institutional frameworks and individual level practices. However, this transformation is difficult to capture [100]. Previous research has confirmed insight into the differences in institutional development between countries even within the Central and Eastern European region [101], and has highlighted the variation firm level factors may cause in individual perceptions $[19,97,102]$.

\section{Conclusions and Implications}

This paper demonstrates the positive relationship between leadership practices and ethical values in private and government business sectors in the Central European Visegrád countries. The results show, that the last generation of value-oriented leadership theory is only truly capable of explaining the whole spectrum of ethical values of the respondents. We also provide evidence for the presence of a gap, spanning between individual level attitudes and aggregate outcomes. The results of this paper-in light of empirical evidence presented by other researchers-imply that the reason for the 
gap between micro and macro level manifestation of institutions cannot be explained by the disconnect between leadership practices and ethical values.

\subsection{Theoretical Implications}

Theoretical implications based on the results are twofold. Firstly, the evidence provided for the strong link between leadership practices and ethical values suggests the possibility of a continuous effort of integrating ethical aspects into currently existing leadership theories. This possibility for incremental theoretical development feeds into the need for further research pointed out by Levine and Boaks [21], on values-based leadership [35]. On the other hand, a fundamental re-thinking of the relationship between ethics and leadership as proposed by Hornett and Fredricks [22] is not warranted. Given the large number of leadership models already in existence $[43,44]$, the real challenge for theorists is either to find the model best suited for incorporating an ethical dimension, or to consolidate the portfolio of models in a way that allows for the emergence of an ethics driven model at the same time.

In particular, we need to highlight our result, in terms of reflecting on the progress of leadership theory development [35]. While trait (generation one), action (generation two), or context (generation three) based leadership theories are not able to holistically capture the relationship between ethics and leadership, value-based leadership theory (generation four) is. This validates the necessity of the new generation of leadership theories, when researching ethical leadership.

Further theoretical implications are driven by the outcome related to the value-action gap. Ethical leadership theorists suggested that ethical leadership at an individual level shapes collective outcomes $[17,18,41]$. In light of the results of this paper, it can be concluded that individual level leadership ethics is a necessary, but by no means a sufficient condition to achieving greater good at a societal level. Therefore, researchers inspiring to tackle the issue of leadership at a societal level will need explore further dimensions of influences going beyond what current leadership theory has already addressed [36].

\subsection{Practical Implications}

Practical implications of the results of this research can be targeted at three particular audiences. Leaders in business, government, or the third sector wishing to inspire ethical attitudes in their subordinates in the Central European Visegrád countries need to foster an organizational culture of teamwork, cultural tolerance, and openness. In terms of facilitating teamwork, leaders need to listen, delegate, be objective, and logical. Openness can be enhanced by demonstrating dependability, trustworthiness, consistency, and accountability, by taking initiative, being practical, and communicating clearly both verbally and in writing. In terms of cultural tolerance, leaders need to be open to integrate positive aspects and contributions of a diverse workforce, and foster an international perspective within the organization. This latter recommendation may prove to be challenging in the current political climate in the region.

The second audience-which is in a position to actually shape leadership behaviors and ethical attitudes-is educators. In order to enhance the awareness of the link between leadership and ethics, educators can incorporate these issues into the curriculum.

Finally, the political elite of these countries-with hands on experience of systemic change and transformation - need to be aware of the value-action gap and the human capital available in their respective nations in terms of ethical leadership capabilities. For them, the greatest challenge is to facilitate these capabilities to emerge and positively influence the institutional environment in their countries.

\subsection{Limitations and Further Research Direction}

As with every single source study, based on self-reported measures, common method variance is a potential issue [103]. Although much of the concern for the common method bias in this research is alleviated by the use of established measures, an emphasis of establishing discriminant validity 
between the dimensions [104] and the use of multiple country samples in establishing invariance [105], validation of the outcomes by further qualitative research creating a narrative to the outcomes may be viewed as desirable.

We also recognize that the scales presented have some validity and reliability issues. In order to achieve the necessary levels of convergent validity, several indicators were discarded during the scale refinement process. This, however, negatively impacts face validity of the scales, and in particular, narrows their scope. Although reliability of the scales was considered sufficient (most Cronbach's Alpha soccer were greater than 0.6 ), in case of scales with only two indicators, it was not possible to conduct a robust reliability assessment. Further analysis—such as confirmatory factor analysis—can alleviate validity and reliability issues by presenting a strong measurement model fit. Although the authors did not proceed with such analysis in this article, as the exploratory analysis of the scales was considered sufficient, such analysis may be conducted for the purposes of further research, and potentially after collection of more primary data.

Furthermore, representativeness of the sample may be questionable, due to the predominantly convenience-based sampling methods employed. In such multi-country studies, it can be difficult to harmonize the data collection methods. Validation of representativeness was conducted by comparing main demographic characteristics of the sample to the total populations in each country respectively. Even though this may be considered sufficient for this research, there is a risk that repeated sampling may deliver different results, therefore further validation of the outcomes by collecting additional data may be sought in future research.

Besides representativeness of the sample, the age of the data may also raise questions. The survey data was collected in 2013, and in several cases, old data can be considered insufficient to drive practical or theoretical conclusions. We argue, that this is not the case in terms of leadership and ethics research. Prominent authors in the field find, that culture itself-related to leadership and ethics—is robust and does not change rapidly over time [49-53]. In fact, the change perceived by researchers is often more strongly due to the shifting perspective [54]. Our research endeavored to consider all four generations of leadership research perspectives currently known. In this sense, we consider the data-regardless of its age-sufficient for the purpose of reflecting on our hypotheses.

The gap between micro and macro level institutional outcomes identified by the results provides further avenues for potential research. Theory suggests, that this discrepancy can be explained by firm level Donadelli et al. [102] or institutional [99] factors, which requires further investigation to ascertain the source of this discrepancy. A multi-level empirical design [106] integrating individual, firm, and country level information in one analysis may provide an approach that is more successful in identifying the reason for the value-action gap. Although gaps spanning between firm and other levels have been recently addressed $[19,99,102]$, systematic investigation using a multi-level approach could allow for further insights and amalgamate findings from different levels into an integrated theory of ethical business conduct.

Another avenue for further research could be taking the perspective of change over time. There is a possibility, that cultural change at an individual level needs time to take effect in terms of the aggregate outcomes. Longitudinal studies-encompassing the change of attitudes and values, and institutions-could show whether there is a difference in terms of the speed of change between the individual and the aggregate levels of observations. Finally, a qualitative study could potentially help in exploring the causes of the gap between micro and macro level institutional performance by allowing individual level reflection on the phenomenon.

Author Contributions: Conceptualization, C.S. and Á.P.; methodology, C.S., Á.P., Z.T., J.T., M.M. and B.T.-B.; formal analysis, Á.P.; data curation, Á.P., M.M., Z.T., B.T.-B. and A.O.-C.; writing-original draft preparation, Á.P., C.S., J.T. and A.O.-C.; writing-review and editing, Á.P.; project administration, Á.P., Z.T., M.M., B.T.-B. and A.O.-C.; funding acquisition, Á.P., J.T., Z.T., M.M. and A.O.-C. All authors have read and agree to the published version of the manuscript. 
Funding: This research was in part funded by the International Visegrád Fund (Standard Grant \# 21220297). The APC was funded by Swinburne University of Technology.

Acknowledgments: The authors acknowledge the generous in-kind contributions of project partner institutions and hard work of their representatives (not listed as authors) from Tomas Bata University (Sarka Fialova), Budapest University of Technology and Economics (Dietmar Meyer), Hungarian Economic Association (Tamas Halm, Miklos Gabor Nagy), The Maria Grzegorzewska Academy of Special Education (Maciej Tanaś, Andrzej Chudzik, Maciej Tysarowski, Mariusz Fila), The Helena Chodkowska University of Management and Law (Ryszard Grosset, Rafal Uhl, Marcin Anszczak) and Matej Bel University (Dana Bencikova, Maria Sekova, Anna Vanova, Tamara Kurilova). Full details of the project are available at: https://sites.google.com/site/v4lead/home.

Conflicts of Interest: The authors declare no conflict of interest.

\section{Appendix A : Respondent Demographics}

Table A1. Respondent demographics in the Czech Republic and Hungary.

\begin{tabular}{|c|c|c|c|c|c|c|c|c|c|}
\hline & & \multicolumn{4}{|c|}{ Czech Republic } & \multicolumn{4}{|c|}{ Hungary } \\
\hline & & $\#$ & $\%$ & Valid \% & $\begin{array}{c}\text { National } \\
\text { Figures \% }\end{array}$ & $\#$ & $\%$ & Valid \% & $\begin{array}{c}\text { National } \\
\text { Figures \% }\end{array}$ \\
\hline \multirow{5}{*}{ Gender } & Male & 96 & 43.6 & 44.7 & $\begin{array}{c}56.8^{1} \\
(74.2)^{2}\end{array}$ & 115 & 57.2 & 58.1 & $53.7^{6}$ \\
\hline & Female & 119 & 54.1 & 55.3 & $\begin{array}{c}43.2^{1} \\
(25.5)^{2}\end{array}$ & 83 & 41.3 & 41.9 & 46.3 \\
\hline & Total valid & 215 & 97.7 & 100 & & 198 & 98.5 & 100 & \\
\hline & Missing & 5 & 2.3 & & & 3 & 1.5 & & \\
\hline & Total & 220 & 100 & & & 201 & 100 & & \\
\hline \multirow{6}{*}{ Sector } & Private & 151 & 68.6 & 71.9 & $74.8^{3}$ & 112 & 55.7 & 58.3 & $67.9^{7}$ \\
\hline & Government & 36 & 16.4 & 17.1 & $25.2^{3}$ & 68 & 33.8 & 35.4 & $28.1^{7}$ \\
\hline & NGO & 23 & 10.5 & 11 & 4 & 12 & 6 & 6.3 & 8 \\
\hline & Total valid & 210 & 95.5 & 100 & & 192 & 95.5 & 100 & \\
\hline & Missing & 10 & 4.5 & & & 9 & 4.5 & & \\
\hline & Total & 220 & 100 & & & 201 & 100 & & \\
\hline \multirow{9}{*}{ Age } & $<25$ & 26 & 11.8 & 12 & $6.3^{5}$ & 6 & 3 & 3 & $5.6^{9}$ \\
\hline & $25-35$ & 83 & 37.7 & 38.4 & $24.9^{5}$ & 48 & 23.9 & 24.1 & $26.1^{9}$ \\
\hline & $36-45$ & 60 & 27.3 & 27.8 & $28.6^{5}$ & 56 & 27.9 & 28.1 & $29.6^{9}$ \\
\hline & $46-55$ & 37 & 16.8 & 17.1 & $24.1^{5}$ & 48 & 23.9 & 24.1 & $24.7^{9}$ \\
\hline & $56-65$ & 9 & 4.1 & 4.2 & $14.5^{5}$ & 37 & 18.4 & 18.6 & $13.1^{9}$ \\
\hline & $65<$ & 1 & 0.5 & 0.5 & $1.6^{5}$ & 4 & 2 & 2 & $0.9^{9}$ \\
\hline & Total valid & 216 & 98.2 & 100 & & 199 & 99 & 100 & \\
\hline & Missing & 4 & 1.8 & & & 2 & 1 & & \\
\hline & Total & 220 & 100 & & & 201 & 100 & & \\
\hline
\end{tabular}

${ }^{1}$ Based on total employment statistics, year 2012 [107]; ${ }^{2} 2011$ data on managerial employment displayed in brackets [108]; ${ }^{3}$ Employment (FTE) based calculations of 2010 [108]; ${ }^{4}$ Included in private sector employment. Estimated to be $1.2 \%$ of total employment using the figures provided by the Czech Statistical Office [108]. Others estimate this ratio between 1.89\% (excl. voluntary work) - 2.42\% (incl. voluntary work) for 2009 [109]; ${ }^{5}$ Employment (FTE) based calculations of 2011 [108], based on standard age classification; ${ }^{6}$ Based on total employment statistics, year 2012 [107]; ${ }^{7}$ Based on full time employment statistics, $2012[110] ;{ }^{8}$ Based on reported number of general employment and full-time employees for 2009, estimated share of NGO employment is 3.5-4\% [111], included in private sector employment; ${ }^{9}$ Based on total employment statistics of year 2012 [110]. 
Table A2. Respondent demographics in Poland and the Slovak Republic.

\begin{tabular}{|c|c|c|c|c|c|c|c|c|c|}
\hline & & \multicolumn{4}{|c|}{ Poland } & \multicolumn{4}{|c|}{ Slovak Republic } \\
\hline & & $\#$ & $\%$ & Valid \% & $\begin{array}{c}\text { National } \\
\text { Figures \% }\end{array}$ & $\#$ & $\%$ & Valid \% & $\begin{array}{c}\text { National } \\
\text { Figures \% }\end{array}$ \\
\hline \multirow{5}{*}{ Gender } & Male & 115 & 50.7 & 50.7 & $55.5^{10}$ & 109 & 49.5 & 50.5 & $\begin{array}{c}56.0^{14} \\
(69.0)^{15}\end{array}$ \\
\hline & Female & 112 & 49.3 & 49.3 & $44.5^{10}$ & 107 & 48.6 & 49.5 & $\begin{array}{c}44.0^{14} \\
(31.0)^{15}\end{array}$ \\
\hline & Total valid & 227 & 100 & 100 & & 216 & 98.2 & 100 & \\
\hline & Missing & 0 & 0 & & & 4 & 1.8 & & \\
\hline & Total & 227 & 100 & & & 220 & 100 & & \\
\hline \multirow{6}{*}{ Sector } & Private & 127 & 55.9 & 57.5 & $77.7^{11}$ & 140 & 63.6 & 65.7 & $73.2 \%{ }^{16}$ \\
\hline & Government & 54 & 23.8 & 24.4 & $22.3^{11}$ & 69 & 31.4 & 32.4 & $26.8 \%^{16}$ \\
\hline & NGO & 40 & 17.6 & 18.1 & 12 & 4 & 1.8 & 1.9 & 17 \\
\hline & Total valid & 221 & 97.4 & 100 & & 213 & 96.8 & 100 & \\
\hline & Missing & 6 & 2.6 & & & 7 & 3.2 & & \\
\hline & Total & 227 & 100 & & & 220 & 100 & & \\
\hline \multirow{9}{*}{ Age } & $<25$ & 8 & 3.5 & 3.5 & $7.3^{13}$ & 8 & 3.6 & 3.7 & $6.5^{18}$ \\
\hline & $25-35$ & 78 & 34.4 & 34.4 & $27.9^{13}$ & 73 & 33.2 & 33.3 & $27.5^{18}$ \\
\hline & $36-45$ & 59 & 26 & 26 & $26.5^{13}$ & 56 & 25.5 & 25.6 & $27.2^{18}$ \\
\hline & $46-55$ & 37 & 16.3 & 16.3 & $23.1^{13}$ & 54 & 24.5 & 24.7 & $26.2^{18}$ \\
\hline & $56-65$ & 38 & 16.7 & 16.7 & $13.6^{13}$ & 27 & 12.3 & 12.3 & $12.1^{18}$ \\
\hline & $65<$ & 7 & 3.1 & 3.1 & $1.6^{13}$ & 1 & 0.5 & 0.5 & $0.5^{18}$ \\
\hline & Total valid & 227 & 100 & 100 & & 219 & 99.5 & 100 & 219 \\
\hline & Missing & 0 & 0 & & & 1 & 0.5 & & 1 \\
\hline & Total & 227 & 100 & & & 220 & 100 & & \\
\hline
\end{tabular}

10 Based on total employment statistics, year 2012 [107]. In $201348 \%$ of senior managers in Poland were female [112]; ${ }^{11}$ Based on total employment statistics, year 2012 [113]; ${ }^{12}$ Included in private sector employment, estimated to be less than 1\% of total employment [114]. Przewłocka et al. [115] in their earlier work specifically estimate the total FTE employment at around $0.64 \%$ of total employment in Poland; ${ }^{13}$ Based on total employment statistics, qIV/2012 data. [113]; ${ }^{14}$ Based on total employment statistics, year 2012 [107]; ${ }^{15} 2011$ data on managerial employment displayed in brackets [116]; ${ }^{16}$ Based on total employment statistics of year 2011 [116]; ${ }^{17}$ Included in private sector employment. Estimated to be $1.1 \%$ of total employment using the figures provided by Strečanský [117] for 2010;

18 Based on total employment statistics of year 2011 [117].

\section{Appendix B : Scales}

The complete questionnaire is available from the authors upon request.

\begin{tabular}{|c|c|c|c|c|c|}
\hline \multirow{2}{*}{ LEADERSHIP EXCELLENCE } & \multicolumn{5}{|c|}{ Loadings } \\
\hline & $\mathrm{CZ}$ & HU & SK & PL & All V4 \\
\hline Eigenvalue of factor & $(2.56)$ & $(2.56)$ & $(2.50)$ & $(2.92)$ & $(2.63)$ \\
\hline Motivate employees & 0.79 & 0.73 & 0.79 & 0.82 & 0.79 \\
\hline Have a strategic vision for the organization & 0.79 & 0.67 & 0.69 & 0.78 & 0.74 \\
\hline $\begin{array}{c}\text { Create a sense of purpose and enthusiasm in the } \\
\text { work place }\end{array}$ & 0.72 & 0.70 & 0.73 & 0.81 & 0.74 \\
\hline Give recognition for good work & 0.71 & 0.78 & 0.74 & 0.79 & 0.76 \\
\hline $\begin{array}{c}\text { Develop strategies to gain a competitive edge in } \\
\text { the industry }\end{array}$ & 0.54 & 0.69 & 0.57 & 0.60 & 0.58 \\
\hline Cronbach's Alpha & 0.75 & 0.76 & 0.74 & 0.80 & 0.76 \\
\hline Total/Average Variance Extracted (AVE) & $51.2 \%$ & $51.2 \%$ & $50.0 \%$ & $58.4 \%$ & $52.4 \%$ \\
\hline
\end{tabular}




\begin{tabular}{|c|c|c|c|c|c|}
\hline \multirow{2}{*}{$\begin{array}{l}\text { ENVIRONMENTAL INFLUENCES } \\
\text { CULTURAL TOLERANCE }\end{array}$} & \multicolumn{5}{|c|}{ Loadings } \\
\hline & $\mathrm{CZ}$ & HU & SK & PL & All V4 \\
\hline Eigenvalue of factor & $(2.23)$ & $(2.68)$ & $(2.74)$ & $(2.97)$ & $(2.70)$ \\
\hline Look for and use the positive aspects of other cultures & 0.81 & 0.69 & 0.83 & 0.83 & 0.82 \\
\hline Have a multicultural orientation and approach & 0.83 & 0.83 & 0.88 & 0.88 & 0.86 \\
\hline Foster an international perspective in the organisation & 0.56 & 0.79 & 0.70 & 0.74 & 0.69 \\
\hline Identify social trends which may have an impact on work & 0.62 & 0.56 & 0.52 & 0.57 & 0.58 \\
\hline Cronbach's Alpha & 0.69 & 0.74 & 0.77 & 0.79 & 0.76 \\
\hline Average Variance Extracted (AVE) & 0.51 & 0.53 & 0.55 & 0.58 & 0.55 \\
\hline ENVIRONMENTAL AWARENESS \& SCREENING & $\mathrm{CZ}$ & HU & SK & PL & All V4 \\
\hline Eigenvalue of factor & $(1.45)$ & $(1.05)$ & $(1.25)$ & $(1.15)$ & $(1.18)$ \\
\hline Constantly evaluate emerging technologies & 0.84 & 0.80 & 0.89 & 0.87 & 0.85 \\
\hline Check constantly for problems and opportunities & 0.80 & 0.82 & 0.86 & 0.88 & 0.85 \\
\hline Spearman's correlation & $0.45^{* *}$ & $0.42 * *$ & $0.57^{* *}$ & $0.60 * *$ & $0.51^{* *}$ \\
\hline Average Variance Extracted & 0.67 & 0.66 & 0.76 & 0.76 & 0.72 \\
\hline Total Variance Extracted (by all factors) & $61.2 \%$ & $62.1 \%$ & $66.4 \%$ & $68.7 \%$ & $64.6 \%$ \\
\hline
\end{tabular}

** significant at $p<0.01$.

\begin{tabular}{|c|c|c|c|c|c|}
\hline \multirow{2}{*}{ MANAGERIAL BEHAVIORS PRACTICALITY } & \multicolumn{5}{|c|}{ Loadings } \\
\hline & $\mathrm{CZ}$ & HU & SK & PL & All V4 \\
\hline Eigenvalue of factor & $(1.04)$ & $(1.46)$ & $(1.35)$ & $(0.87)$ & $(0.94)$ \\
\hline Focus on the task-in-hand & 0.73 & 0.74 & 0.88 & 0.84 & 0.87 \\
\hline Think about the specific details of any particular problem & 0.71 & 0.78 & 0.76 & 0.73 & 0.68 \\
\hline Spearman's correlation & $0.22 * *$ & $0.29 * *$ & 0.39 ** & $0.33^{* *}$ & $0.31^{* *}$ \\
\hline Average Variance Extracted (AVE) & 0.52 & 0.58 & 0.65 & 0.62 & 0.61 \\
\hline
\end{tabular}

** significant at $p<0.01$.

\begin{tabular}{ccccccc}
\hline TEAMWORK & CZ & HU & SK & PL & All V4 \\
\hline Eigenvalue of factor & $(0.96)$ & $(0.93)$ & $(1.06)$ & $(1.37)$ & $(1.13)$ \\
\hline Allow subordinates authority and autonomy & 0.83 & 0.83 & 0.82 & 0.86 & 0.84 \\
\hline Consider suggestions made by employees & 0.64 & 0.73 & 0.79 & 0.77 & 0.75 \\
\hline Spearman's correlation & $0.16^{*}$ & $0.33^{* *}$ & $0.34^{* *}$ & $0.41^{* *}$ & $0.36^{* *}$ \\
\hline Average Variance Extracted (AVE) & 0.55 & 0.62 & 0.65 & 0.67 & 0.63 \\
\hline
\end{tabular}

* significant at $p<0.05 ;{ }^{* *}$ significant at $p<0.01$. 


\begin{tabular}{|c|c|c|c|c|c|}
\hline DECISIVENESS & $\mathrm{CZ}$ & HU & SK & PL & All V4 \\
\hline Eigenvalue of factor & $(2.41)$ & $(2.20)$ & $(2.25)$ & $(2.62)$ & $(2.40)$ \\
\hline Make work decisions quickly & 0.87 & 0.83 & 0.81 & 0.82 & 0.81 \\
\hline Make decisions earlier rather than later & 0.73 & 0.66 & 0.57 & 0.71 & 0.66 \\
\hline Make decisions without depending too much on others & 0.68 & 0.73 & 0.85 & 0.82 & 0.80 \\
\hline Cronbach's Alpha & 0.69 & 0.63 & 0.67 & 0.73 & 0.67 \\
\hline Average Variance Extracted (AVE) & 0.58 & 0.55 & 0.57 & 0.62 & 0.57 \\
\hline Total Variance Extracted (by all factors) & $62.9 \%$ & $65.5 \%$ & $66.7 \%$ & $69.4 \%$ & $66.1 \%$ \\
\hline \multirow{2}{*}{ ORGANIZATIONAL DEMANDS } & \multicolumn{5}{|c|}{ Loadings } \\
\hline & $\mathrm{CZ}$ & HU & SK & PL & All V4 \\
\hline Eigenvalue of factor & $(1.71)$ & $(1.44)$ & $(1.58)$ & $(1.70)$ & $(1.61)$ \\
\hline Act as a member of a team & 0.76 & 0.65 & 0.74 & 0.72 & 0.74 \\
\hline Support decisions made jointly by others & 0.79 & 0.66 & 0.77 & 0.82 & 0.77 \\
\hline $\begin{array}{l}\text { Sell the professional image or corporate image to } \\
\text { the public }\end{array}$ & 0.72 & 0.77 & 0.66 & 0.71 & 0.69 \\
\hline Cronbach's Alpha & 0.61 & 0.46 & 0.55 & 0.61 & 0.56 \\
\hline Total/Average Variance Extracted (AVE) & $57.1 \%$ & $48.1 \%$ & $52.8 \%$ & $56.7 \%$ & $53.7 \%$ \\
\hline PERSONAL QUALITIES & \multicolumn{5}{|c|}{ Loadings } \\
\hline OPENNESS & $\mathrm{CZ}$ & HU & SK & PL & All V4 \\
\hline Eigenvalue of factor & $(1.78)$ & $(1.55)$ & $(1.05)$ & $(1.71)$ & $(1.71)$ \\
\hline Be consistent in dealing with people & 0.86 & 0.77 & 0.84 & 0.85 & 0,84 \\
\hline Accept responsibility for mistakes & 0.88 & 0.83 & 0.73 & 0.86 & 0,84 \\
\hline Spearman's correlation & $0.51 * *$ & $0.39 * *$ & $0.24 * *$ & $0.41 * *$ & $0.39^{* *}$ \\
\hline Average Variance Extracted (AVE) & 0.77 & 0.64 & 0.62 & 0.73 & 0.71 \\
\hline
\end{tabular}

** significant at $p<0.01$.

\begin{tabular}{cccccc}
\hline MORAL VIRTUE & CZ & HU & SK & PL & All V4 \\
\hline Eigenvalue of factor & $(1.22)$ & $(1.16)$ & $(1.72)$ & $(1.28)$ & $(1.65)$ \\
\hline Follow the heart—not the head - in compassionate matters & 0.86 & 0.86 & 0.85 & 0.88 & 0.87 \\
\hline $\begin{array}{c}\text { Follow what is morally right - not what is right for self } \\
\text { or organization }\end{array}$ & 0.82 & 0.75 & 0.86 & 0.82 & 0.81 \\
\hline Spearman's correlation & $0.43^{* *}$ & $0.30^{* *}$ & $0.48^{* *}$ & $0.43^{* *}$ & $0.41^{* *}$ \\
\hline Average Variance Extracted (AVE) & 0.71 & 0.65 & 0.73 & 0.72 & 0.71 \\
\hline Total Variance Extracted (by all factors) & $75.0 \%$ & $67.6 \%$ & $69.1 \%$ & $74.7 \%$ & $71.9 \%$ \\
\hline
\end{tabular}

** significant at $p<0.01$. 


\begin{tabular}{|c|c|c|c|c|c|}
\hline \multirow{2}{*}{$\begin{array}{l}\text { ETHICAL ATTITUDES } \\
\text { NEGATIVE PATTERNS }\end{array}$} & \multicolumn{5}{|c|}{ Loadings } \\
\hline & $\mathrm{CZ}$ & HU & SK & PL & All V4 \\
\hline Eigenvalue of factor & $(3.90)$ & $(4.26)$ & $(3.89)$ & $(3.13)$ & $(3.69)$ \\
\hline $\begin{array}{l}\text { Understand that engaging in corruption is a way "things } \\
\text { get done." }\end{array}$ & 0.86 & 0.92 & 0.86 & 0.83 & 0.88 \\
\hline $\begin{array}{c}\text { Recognize that bribes are often necessary means to } \\
\text { achieve outcomes. }\end{array}$ & 0.83 & 0.91 & 0.85 & 0.82 & 0.86 \\
\hline Accept corruption as a part of doing business. & 0.79 & 0.91 & 0.86 & 0.54 & 0.81 \\
\hline View deception as a necessity. & 0.76 & 0.75 & 0.74 & 0.81 & 0.76 \\
\hline View corruption as a tool of competing effectively. & 0.74 & 0.92 & 0.82 & 0.75 & 0.83 \\
\hline $\begin{array}{l}\text { View accountability, compliance and transparency } \\
\text { as luxuries. }\end{array}$ & 0.60 & 0.47 & 0.67 & 0.48 & 0.54 \\
\hline Cronbach's Alpha & 0.86 & 0.90 & 0.89 & 0.77 & 0.86 \\
\hline Average Variance Extracted (AVE) & 0.59 & 0.69 & 0.65 & 0.52 & 0.60 \\
\hline POSITIVE PATTERNS & $\mathrm{CZ}$ & HU & SK & PL & All V4 \\
\hline Eigenvalue of factor & $(1.97)$ & $(2.40)$ & 2.76) & $(2.84)$ & $(2.26)$ \\
\hline $\begin{array}{l}\text { Consider the consequences of decisions that } \\
\text { affect stakeholders. }\end{array}$ & 0.82 & 0.78 & 0.83 & 0.83 & 0.83 \\
\hline $\begin{array}{l}\text { Assess different stakeholder claims before } \\
\text { making decisions. }\end{array}$ & 0.74 & 0.82 & 0.84 & 0.87 & 0.83 \\
\hline Be aware of relevant stakeholder's claims. & 0.72 & 0.76 & 0.84 & 0.80 & 0.79 \\
\hline $\begin{array}{l}\text { Involve the affected stakeholders in the decision } \\
\text { making process. }\end{array}$ & 0.67 & 0.79 & 0.80 & 0.81 & 0.77 \\
\hline Cronbach's Alpha & 0.73 & 0.79 & 0.85 & 0.86 & 0.82 \\
\hline Average Variance Extracted (AVE) & 0.54 & 0.62 & 0.69 & 0.69 & 0.65 \\
\hline Total Variance Extracted (by all factors) & $58.7 \%$ & $66.6 \%$ & $66.6 \%$ & $59.8 \%$ & $62.5 \%$ \\
\hline
\end{tabular}

\section{References}

1. Acemoglu, D.; Johnson, S.; Robinson, J.A. Institutions as the Fundamental Cause of Long-Run Growth. In Handbook of Economic Growth; Aghion, P., Durlauf, S., Eds.; Elsevier: Amsterdam, The Netherlands, 2005; ISBN 9780444520418.

2. Acemoglu, D.; Robinson, J.A. The Role of Institutions in Growth and Development. Rev. Econ. Inst. 2010, 1, 1-33. [CrossRef]

3. North, D. Institutions, Institutional Change and Economic Performance; Cambridge University Press: Cambridge, UK, 1990; ISBN 9780521397346.

4. Hodgson, G.M. A Modern Reader in Institutional and Evolutionary Economics; Edward Elgar: Celtenham, UK, 2003; ISBN 9781840644746.

5. March, J.G.; Olsen, J.P. Elaborating the "New Institutionalism". In The Oxford Handbook of Political Institutions; Binder, S.A., Rhodes, R.A.W., Rockman, B.A., Eds.; Oxford University Press: Oxford, UK, 2008; ISBN 9780199548460.

6. North, D. Institutions. J. Econ. Perspect. 1991, 5, 97-112. [CrossRef]

7. Von Schirnding, Y. The World Summit on Sustainable Development: Reaffirming the centrality of health. Glob. Health 2005, 1, 8-14. [CrossRef] [PubMed]

8. Coase, R.H. The Problem of Social Cost. J. Law Econ. 1960, 3, 1-44. [CrossRef] 
9. Todaro, M.P.; Smith, S.C. Economic Development; Pearson Addison Wesley: Boston, MA, USA, 2015; ISBN 978-0138013882.

10. Vaduva, S.; Fotea, I.S.; Thomas, A.R. Business Ethics and Leadership from an Eastern European, Transdisciplinary Context; Springer: Cham, Switzerland, 2017; ISBN 9783319451862.

11. Price, T.L. A “critical leadership ethics" approach to the Ethical Leadership construct. Leadership 2018, 14, 687-706. [CrossRef]

12. Flanigan, J. Philosophical methodology and leadership ethics. Leadership 2018, 14, 707-730. [CrossRef]

13. Palanski, M.; Newman, A.; Leroy, H.; Moore, C.; Hannah, S.; Den Hartog, D. Quantitative research on leadership and business ethics: Examining the state of the field and an agenda for future research. J. Bus. Ethics 2019, 1-11. [CrossRef]

14. Ko, C.; Ma, J.; Bartnik, R.; Haney, M.H.; Kang, M. Ethical Leadership: An Integrative Review and Future Research Agenda. Ethics Behav. 2018, 28, 104-132. [CrossRef]

15. McCann, J.; Holt, R. Ethical Leadership and Organizations: An Analysis of Leadership in the Manufacturing Industry Based on the Perceived Leadership Integrity Scale. J. Bus. Ethics 2009, 87, 211-220. [CrossRef]

16. Voegtlin, C.; Patzer, M.; Scherer, A.G. Responsible Leadership in Global Business: A New Approach to Leadership and Its Multi-Level Outcomes. J. Bus. Ethics 2012, 105, 1-16. [CrossRef]

17. Poff, D.C. Ethical Leadership and Global Citizenship: Considerations for a Just and Sustainable Future. J. Bus. Ethics 2010, 93, 9-14. [CrossRef]

18. Brown, M.E.; Treviño, L.K. Ethical leadership: A review and future directions. Leadersh. Q. 2006, 17, 595-616. [CrossRef]

19. De Jong, G.; Van Ees, H. Firms and Corruption. Eur. Manag. Rev. 2014, 11, 187-190. [CrossRef]

20. Ciulla, J.B. Leadership Ethics: Mapping the Territory. Bus. Ethics Q. 1995, 5, 5-28. [CrossRef]

21. Levine, M.P.; Boks, J. What does Ethics Have to do with Leadership? J. Bus. Ethics 2014, 124, $225-242$. [CrossRef]

22. Hornett, A.; Fredricks, S. An Empirical and Theoretical Exploration of Disconnections between Leadership and Ethics. J. Bus. Ethics 2005, 59, 233-246. [CrossRef]

23. Harshman, C.L.; Harshman, E.F. The Gordian Knot of Ethics: Understanding Leadership Effectiveness and Ethical Behavior. J. Bus. Ethics 2008, 78, 175-192. [CrossRef]

24. Mozumder, N.A. A Multilevel Trust-based Model of Ethical Public Leadership. J. Bus. Ethics 2016, 153, 167-184. [CrossRef]

25. Effelsberg, D.; Solga, M.; Gurt, J. Transformational Leadership and Follower's Unethical Behavior for the Benefit of the Company: A Two-Study Investigation. J. Bus. Ethics 2014, 120, 81-93. [CrossRef]

26. Hansen, S.D.; Alge, B.J.; Brown, M.E.; Jackson, C.L.; Dunford, B.B. Ethical Leadership: Assessing the Value of a Multifoci Social Exchange Perspective. J. Bus. Ethics 2013, 119, 435-449. [CrossRef]

27. Khuntia, R.; Suar, D. A Scale to Assess Ethical Leadership of Indian Private and Public Sector Managers. J. Bus. Ethics 2004, 49, 13-26. [CrossRef]

28. Nguyen, N.T.; Biderman, M.D. Studying Ethical Judgments and Behavioral Intentions Using Structural Equations: Evidence from the Multidimensional Ethics Scale. J. Bus. Ethics 2008, 83, 627-640. [CrossRef]

29. Reed, L.; Vidaver-Cohen, D.; Colwell, S. A New Scale to Measure Executive Servant Leadership: Development, Analysis, and Implications for Research. J. Bus. Ethics 2011, 101, 415-434. [CrossRef]

30. Resick, C.J.; Martin, G.S.; Keating, M.A.; Dickson, M.W.; Kwan, H.K.; Peng, C. What ethical leadership means to me: Asian, American, and European perspectives. J. Bus. Ethics 2011, 101, 435-457. [CrossRef]

31. Eisenbeiss, S.A.; Brodbeck, F. Ethical and Unethical Leadership: A Cross-Cultural and Cross-Sectoral Analysis. J. Bus. Ethics 2015, 122, 343-359. [CrossRef]

32. Marsh, C. Business Executives' Perceptions of Ethical Leadership and Its Development. J. Bus. Ethics 2013, 114, 565-582. [CrossRef]

33. Pucic, J. Do as I Say (and do): Ethical Leadership through the Eyes of Lower Ranks. J. Bus. Ethics 2015, 129, 655-671. [CrossRef]

34. Painter-Morland, M. Systemic Leadership and the Emergence of Ethical Responsiveness. J. Bus. Ethics 2008, 82, 509-524. [CrossRef]

35. Yinghong, S.W.; O'Neill, H.; Zhou, N. How does perceived integrity in leadership matter to firms in a transitional economy? J. Bus. Ethics 2019, 1-19. [CrossRef] 
36. Dionne, S.D.; Gupta, A.; Sotak, K.L.; Shirreffs, K.A.; Serban, A.; Hao, C.; Kim, D.H.; Yammarino, F.J. A 25-year perspective on levels of analysis in leadership research. Leadersh. Q. 2014, 25, 6-35. [CrossRef]

37. Bass, B.M. The Bass Handbook of Leadership: Theory Research, and Managerial Applications; Free Press: New York, NY, USA, 2008; ISBN 9780743215527.

38. Northouse, P.G. Leadership: Theory and Practice; SAGE: Thousand Oaks, CA, USA, 2007; ISBN 9781506362311.

39. Jones, T. Ethical Decision Making by Individuals in Organizations: An Issue-Contingent Model. Acad. Manag. Rev. 1991, 16, 366-395. [CrossRef]

40. Collins, J.; Uhlenbruck, K.; Rodriguez, P. Why Firms Engage in Corruption: A Top Management Perspective. J. Bus. Ethics 2009, 87, 89-108. [CrossRef]

41. Voegtlin, C. Development of a scale measuring discursive responsible leadership. J. Bus. Ethics 2011, 98 (Suppl. 1), 57-73. [CrossRef]

42. Barsky, A. Investigating the Effects of Moral Disengagement and Participation on Unethical Work Behavior. J. Bus. Ethics 2011, 104, 59-75. [CrossRef]

43. Day, D.V.; Fleenor, J.W.; Atwater, L.E.; Strurm, R.E.; McKee, R.A. Advances in leader and leadership development: A review of 25 years of research and theory. Leadersh. Q. 2014, 25, 63-82. [CrossRef]

44. Dinh, J.E.; Lord, R.G.; Gardener, W.L.; Meuser, J.D.; Liden, R.C.; Hu, J. Leadership theory and research in the new millennium: Current theoretical trends and changing perspectives. Leadersh. Q. 2014, 25, 36-62. [CrossRef]

45. Thorne, L.; Saunders, S.B. The Socio-Cultural Embeddedness of Individuals' Ethical Reasoning in Organizations. J. Bus. Ethics 2002, 35, 1-14. [CrossRef]

46. Szelényi, I. Kapitalizmusok, szocializmusok után. Egyenlítő 2004, 2, 2-11.

47. Hofstede, G. Cultural Consequences: International Differences in Work-Related Values; Sage Publication: Thousand Oaks, CA, USA, 2001; ISBN 9780803973237.

48. Laurent, A. The cultural diversity of Western conceptions of management. Int. Stud. Manag. Organ. Sci. 1983, 13, 75-96. [CrossRef]

49. Trompenaars, F. Riding the Waves of Culture: Understanding Cultural Diversity in Business; Brealey: London, UK, 1993; ISBN 9781857881769.

50. Dickson, M.W.; Den Hartog, D.N.; Mitchelson, J.K. Research on leadership in a cross-cultural context: Making progress, and raising new questions. Leadersh. Q. 2003, 14, 729-768. [CrossRef]

51. House, R.J.; Hanges, P.J.; Javidan, M.; Dorfman, P.W.; Gupta, V. Culture, Leadership and Organisations: The GLOBE Study of 62 Societies; Sage Publishing: Thousand Oaks, CA, USA, 2004; ISBN 9780761924012.

52. Hoppe, H. An Interview with Geert Hofstede. Acad. Manag. Exec. 2004, 18, 75-79. [CrossRef]

53. Tung, R.L.; Verbeke, A. Beyond Hofstede and GLOBE: Improving the quality of cross-cultural research. J. Int. Bus. Stud. 2010, 41, 1259-1274. [CrossRef]

54. Fang, T. From 'Onion' to 'Ocean'-Paradox and Change in National Cultures. Int. Stud. Manag. Organ. 2005, 35, 71-90. [CrossRef]

55. Jepson, D. Studying Leadership at Cross-Country Level: A Critical Analysis. Leadership 2009, 5, 61-80. [CrossRef]

56. Brewer, P.; Venaik, S. On the misuse of national culture dimensions. Int. Mark. Rev. 2012, 29, 673-683. [CrossRef]

57. De Mooji, M. On the misuse and misinterpretation of dimensions of national culture. Int. Mark. Rev. 2013, 30, 253-261. [CrossRef]

58. Terrell, R.S.; Rosenbusch, K. How global leaders develop. J. Manag. Dev. 2013, 32, 1056-1079. [CrossRef]

59. Máriás, A.; Kovács, S.; Balaton, K.; Tari, E.; Dobák, M. Kísérlet ipari nagyvállalataink összehasonlító szervezetelemzésére. Közgazdasági Szle 1981, 7-8, 838-852.

60. Bakacsi, G. A leadership-elméletek áttekintése. Közgazdasági Szle 1989, 7-8, 987-997.

61. Mrówka, R. Leadership in Organisations. Analysis of Best Practice. (Przywództwo w Organizacjach. Analiza Najlepszych Praktyk.); Wolters Cluwer: Warszawa, Poland, 2010; ISBN 9788375267341.

62. Stýblo, J. Leadership v Organizaci; Ústav práva a právní vědy: Praha, Czechia, 2013; ISBN 9788090524750.

63. Kets de Vries, M.; Shekshnia, S.; Korotov, K.; Florent-Treacy, E. The New Global Russian Business Leaders: Lessons from a Decade of Transition. Eur. Manag. J. 2004, 22, 637-648. [CrossRef] 
64. Agrawal, A.; Rook, C. Global leaders in East and West-Do all global leaders lead in the same way? In Advances in Global Leadership; Osland, J.S., Li, M., Wang, Y., Eds.; Emerald Group Publishing Limited: Bingley, UK, 2014; Volume 8, pp. 155-179. ISBN 9781783504794.

65. Den Hartog, D.; Koopman, P.; Thierry, H.; Wilderom, C.; Maczynski, J.; Jarmuz, S. Dutch and Polish Perception of Leadership and Culture the GLOBE Project. Eur. J. Work Organ. Psychol. 1997, 6, 387-413. [CrossRef]

66. Wójtowicz, A. Diagnosis of the Company's Organisational Culture. (Diagnozowanie Kultury Organizacyjnej Przedsiębiorstwa); MWSE: Tarnów, Poland, 2002.

67. Bakacsi, G.; Sándor, T.; András, K.; Viktor, I. Eastern European cluster: Tradition and transition. J. World Bus. 2002, 37, 69-80. [CrossRef]

68. North, D.C. Understanding the Process of Economic Change; Princeton University Press: Princeton, NJ, USA, 2005; ISBN 9780691145952.

69. Oliver, C. Sustainable competitive advantage: Combining institutional and resource-based views. Strateg. Manag. J. 1997, 18, 697-713. [CrossRef]

70. Kornai, J. The great transformation of Central Eastern Europe. Econ. Transit. 2006, 14, 207-244. [CrossRef]

71. Berend, T.I. From the Soviet Bloc to the European Union: The Economic and Social Transformation of Central and Eastern Europe Since 1973; Cambridge University Press: New York, NY, USA, 2009; ISBN 9780521729505.

72. World Bank. Doing Business Indicators; World Bank Group: Washington, DC, USA, 2019; Available online: www.doingbusiness.org (accessed on 5 December 2019).

73. Transparency International. Corruption Perceptions Index; Transparency International: Berlin, Germany, 2019; Available online: https://www.transparency.org/research/cpi/overview (accessed on 5 December 2019).

74. World Bank. Worldwide Governance Indicators; World Bank: Washington, DC, USA, 2019; Available online: www.govindicators.org (accessed on 5 December 2019).

75. Pok, A. Atonement and Sacrifice: Scapegoats in Modern Eastern and Central Europe. East Eur. Q. 1999, 32, 531-547.

76. Norris, P. Making Democracies Work: Social Capital and Civic Engagement in 47 Societies. In Proceedings of the European Science Foundation EURESCO Conference on Social Capital: Interdisciplinary Perspectives, Exeter, UK, 15-20 September 2001.

77. Selvarajah, C.; Duignan, P.; Suppiah, C.; Lane, T.; Nuttman, C. In search of the Asian leader: An exploratory study of dimensions that relates to excellence in leadership. Manag. Int. Rev. J. Int. Bus. 1995, 35, $29-34$. [CrossRef]

78. Taormina, R.J.; Selvarajah, C. Perceptions of Leadership Excellence in ASEAN Nations. Leadership 2005, 1, 299-322. [CrossRef]

79. Selvarajah, C. Archetypes of the Malaysian manager: Exploring ethnicity dimensions that relate to leadership. J. Manag. Organ. 2006, 12, 251-269. [CrossRef]

80. Selvarajah, C.; Meyer, D. One nation, three cultures: Exploring dimensions that relate to leadership in Malaysia. Leadersh. Organ. Dev. J. 2008, 29, 693-712. [CrossRef]

81. Selvarajah, C.; Meyer, D. Profiling the Chinese manager: Exploring dimensions that relate to leadership. Leadersh. Organ. Dev. J. 2008, 29, 359. [CrossRef]

82. Selvarajah, C.; Meyer, D.; Davuth, D. The effect of cultural modelling on leadership profiling of the Cambodian manager. Asia Pac. Bus. Rev. 2012, 18, 649-674. [CrossRef]

83. Selvarajah, C.; Meyer, D.; Trung, P.W. In search of excellence in leadership in the Vietnamese manager: Where Confucianism meets Dharma. In Proceedings of the Academy of International Business Southeast Asia Regional Conference, Ho Chi Minh City, Vietnak, 2-4 December 2010.

84. Selvarajah, C.; Meyer, D.; Davuth, D. The effect of cultural modelling on leadership profiling of the Cambodian Manager. In Leadership in the Asia Pacific: A Global Research Perspective; Rowley, C., Ulrich, D., Eds.; Routledge: Abingdon, UK, 2013; ISBN 9781138383036.

85. Selvarajah, C.; Meyer, D.; Sukunesan, S.; Venkatapathy, R. Rise of India Firms-Understanding leadership in Indian organisations. In The Rise of Asian Firms (91-119); Chan, T.S., Cui, G., Eds.; Palgrave Macmillan: London, UK, 2014; ISBN 9781137407719.

86. Selvarajah, C.; Meyer, D.; Donovan, D.J. Flowers in a Greenhouse: Profiling excellence in leadership in Singapore: Shifting values. Leadersh. Organ. Dev. J. 2013, 34, 784-804. [CrossRef] 
87. De Waal, A.A.; Heijden, B.I.J.M.; Selvarajah, C.; Meyer, D. Characteristics of high performing managers in The Netherlands. Leadersh. Organ. Dev. J. 2012, 33, 131-148. [CrossRef]

88. Shrivastava, S.; Selvarajah, C.; Dorasamy, N.; Meyer, D. Exploring Excellence in Leadership perceptions amongst South African Managers. Hum. Resour. Dev. Int. 2014, 17, 47-66. [CrossRef]

89. Selvarajah, C.; Meyer, D.; Donovan, J. Cultural context and its influence on managerial leadership in Thailand. Asia Pac. Bus. Rev. 2013, 19, 356-380. [CrossRef]

90. Harzing, A.-W. Response Styles in Cross-national Survey Research. Int. J. Cross Cult. Manag. 2006, 6, $243-266$. [CrossRef]

91. Harzing, A.-W.; Reiche, S.; Pudelko, M. Challenges in International Survey Research: A review with illustrations and suggested solutions for best practice. Eur. J. Int. Manag. 2013, 7, 112-134. [CrossRef]

92. Hair, J.F.; Black, W.C.; Babin, B.J.; Anderson, R.E.; Tatham, R.L. Multivariate Data Analysis, 6th ed.; Pearson Education International: Upper Saddle River, NJ, USA, 2006; ISBN 9780130329295.

93. Lind, D.A.; Marchal, W.G.; Mason, R.D. Statistical Techniques in Business E Economics, 11th ed.; McGraw-Hill: Sydney, Australia, 2002; ISBN 9780072868241.

94. Fornell, C.; Larcker, D.F. Evaluating Structural Equation Models with Unobservable Variables and Measurement Error. J. Mark. Res. 1981, 18, 39-50. [CrossRef]

95. Ruiz, P.; Ruiz, C.; Martínez, R. Improving the 'Leader-Follower' Relationship: Top Manager or Supervisor? The Ethical Leadership Trickle-Down Effect on Follower Job Response. J. Bus. Ethics 2011, 99, 587-608. [CrossRef]

96. Blake, J. Overcoming the 'value-action gap' in environmental policy: Tensions between national policy and local experience. Local Environ. Int. J. Justice Sustain. 1999, 4, 257-278. [CrossRef]

97. Ajzen, I. The Theory of Planned Behavior. Organ. Behav. Hum. Decis. Process. 1991, 50, 179-211. [CrossRef]

98. Ajzen, I. The theory of planned behaviour: Reactions and reflections. Psychol. Health 2011, 26, 1113-1127. [CrossRef] [PubMed]

99. Frost, J.; Tischer, S. Unmasking Collective Corruption: The Dynamics of Corrupt Routines. Eur. Manag. Rev. 2014, 11, 191-207. [CrossRef]

100. Enderle, G. A Worldwide survey of business ethics in the 1990s. J. Bus. Ethics 1997, 16, 1475-1483. [CrossRef]

101. Palidauskaite, J. Codes of Ethics in Transitional Democracies: A Comparative Perspective. Public Integr. 2006, 8, 35-48. [CrossRef]

102. Donadelli, M.; Fasan, M.; Magnanelli, B.S. The Agency Problem, Financial Performance and Corruption: Country, Industry and Firm Level Perspectives. Eur. Manag. Rev. 2014, 11, 259-272. [CrossRef]

103. Avolio, B.J.; Yammarino, F.J.; Bass, B.M. Identifying common method variance with data collected from a single source: An unresolved sticky issue. J. Manag. 1991, 17, 571-587. [CrossRef]

104. Elangovan, A.R.; Xie, J.L. Effects of perceived power of supervisor on subordinate stress and motivation: The moderating role of subordinate characteristics. J. Organ. Behav. 1999, 20, 359-373. [CrossRef]

105. Chang, S.J.; Van Witteloostuijn, A.; Eden, L. From the Editors: Common method variance in international business research. J. Int. Bus. Stud. 2010, 41, 178-184. [CrossRef]

106. Kozlowski, S.W.J.; Klein, K.J. A multilevel approach to theory and research in organizations: Contextual, temporal, and emergent processes. In Multilevel Theory, Research and Methods in Organizations: Foundations, Extensions, and New Directions; Klein, K.J., Kozlowski, S.W.J., Eds.; Jossey-Bass: San Francisco, CA, USA, 2000; pp. 3-90. ISBN 9780787952280.

107. European Commission. Eurostat Database. 2013. Available online: http://epp.eurostat.ec.europa.eu/portal/ page/portal/statistics/search_database (accessed on 8 November 2013).

108. Czech Statistical Office. Statistical Yearbook of the Czech Republic; Czech Statistical Office: Prague, Czech Republic, 2012.

109. Pospíšil, M.; Prouzová, Z.; Škarabelová, S.; Tumová Almani, K. Czech nonprofit sector twenty years after: Current developments and challenges. Civ. Rev. 2012, 9, 5-22.

110. Hungarian Central Statistical Office. STADAT-Database. 2013. Available online: http://www.ksh.hu/ engstadat (accessed on 9 November 2013).

111. Bartal, A.M.; Nagy, R.; Sebestény, I. Tények és Lehetőségek a Foglalkoztatás Helyzete a Magyar Nonprofit Szektorban; CIVITALIS Association: Budapest, Hungary, 2011. 
112. Groom, B. Women's labour market progress stalls. Financial Times, 7 March 2013 . Available online: http://ig-legacy.ft.com/content/5cc2cc36-8736-11e2-9dd7-00144feabdc0\#axzz6BBkWXI1K (accessed on 9 November 2013).

113. Central Statistical Office Poland. Concise Statistical Yearbook of Poland; Central Statistical Office Poland: Warsaw, Poland, 2013.

114. Przewłocka, J.; Adamiak, P.; Herbst, J. Podstawowe Fakty o Organizacjach Pozarzadowych; Stowarzyszenie Klon/Jawor: Warszawa, Poland, 2013.

115. Przewłocka, J.; Herbst, J.; Gumkowska, M. Polish third sector-Basic overview, key facts, tendencies and challenges. Civ. Rev. 2012, 9, 43-57.

116. Statistical Office of the Slovak Republic. Statistical Yearbook of the Slovak Republic 2012; Statistical Office of the Slovak Republic: Bratislava, Slovakia, 2012.

117. Strečanský, B. The situation of the third sector in Slovakia, the impacts of crisis, trends, mainstreams and challenges. Civ. Rev. 2012, 9, 75-93.

(C) 2020 by the authors. Licensee MDPI, Basel, Switzerland. This article is an open access article distributed under the terms and conditions of the Creative Commons Attribution (CC BY) license (http://creativecommons.org/licenses/by/4.0/). 